\title{
Metalografik İncelemelerle Ray Yüzeyindeki Soyulmaların Nedeninin Araştırılması
}

\author{
Alper Uğur ${ }^{1 *}$, Kemal Davut $^{2,3}$, Rasim Bacac1 $^{4}$ \\ ${ }^{1}$ RAYSIMAŞ (Raylı Sistemler Mühendislik ve Müşavirlik A.Ş.), Ankara, Türkiye (ORCID: 0000-0002-8310-8839) \\ 2 Atılım Üniversitesi, Metalurji ve Malzeme Mühendisliği Bölümü, Ankara, Türkiye (ORCID: 0000-0002-9860-881X) \\ ${ }^{3}$ Atılım Üniversitesi, Metal Şekillendirme Mükemmeliyet Merkez, Ankara, Türkiye \\ ${ }^{4}$ BURULAŞ (Bursa Ulaşım Toplu Taşım İşletmeciliği Turizm San. ve Tic. A.Ş.), Bursa, Türkiye (ORCID: 0000-0002-8588-4946)
}

(İlk Geliş Tarihi 14 Mart 2020 ve Kabul Tarihi 23 Mayıs 2020)

(DOI: $10.31590 /$ ejosat.703669)

\begin{abstract}
ATIF/REFERENCE: Uğur, A., Davut, K. \& Bacacı, R. (2020). Metalografik İncelemelerle Ray Yüzeyindeki Soyulmaların Nedeninin
\end{abstract} Araştırılması. Avrupa Bilim ve Teknoloji Dergisi, (19), 1-18.

\section{Öz}

Demiryolları yolcu ve yük taşımacılığında dünya genelinde giderek artarak kullanılmaktadır. $\mathrm{Bu}$ artan trafik aynı zamanda tren raylarında kusurların daha çabuk ve daha sık görülmesine neden olmaktadır. Bu çalışmada Bursa ilinde kullanılan ve hızlı aşınarak parça kopmaları problemi yaşanan ray setleri incelenmiştir. R260 kalite çelikten imal edilen rayların özellikle kurp bölgesinde problem daha çok görülmektedir. Karşılaştırma yapılabilmesi için daha az sorun yaşanan düz hat bölgesinden alınan raylar da incelenmiştir. Problem yaşanan ray parçalarının yüzeyleri incelendikten sonra ray profilinin mantar bölgesi, yanak (gauge ve field corner) yüzeylerinden numuneler çıkarılarak metalografik inceleme için hazırlanmıştır. Hazırlanan numunelerin mikroyapıları optik mikroskop ve taramalı elektron mikroskobu (SEM) altında incelenmiş, ayrıca Vickers mikro-sertlik testleri yapılmıştır. Taramalı elektron mikroskobuna bağlı enerji dağılımlı X-1şınları spektrometresi (EDS) kullanılarak numuneler üzerinde mikro-kimyasal analizler gerçekleştirilmiştir. Makro-kimyasal analizler için optik emisyon spektrometresi (OES) kullanılmıştır. Ray kesitlerine makro-dağlama yapılarak genel yapı (makro-yapı) kontrol edilmiştir. Yapılan incelemeler sonucunda ray kesitlerinin \% 100 perlitten oluştuğu, öte yandan yük altında olan yanak bölgesinde ise aşırı deformasyon nedeniyle perlit yapısının bozulduğu gözlemlenmiştir. Perlitik yapı aşırı deformasyon etkisiyle mikron altı büyüklüklerde ferrit ve sementite dönüşerek lifli bir yapı halini almıştır. Deformasyon sonucu pekleşen bu yapı çatlak başlangıcına neden olmuştur. Aynı zamanda yapıda bulunan metal dışı kalıntılar (inklüzyon) çatlakların ray içine doğru ilerlemesini kolaylaştırmış ve sonrasında parça kopmalarına neden olmuştur. Çatlakların etrafında demir-oksit partiküllerine rastlanmıştır. Bu durum çatlakların, aniden ilerlemediğini, zaman içinde kullanıma ve atmosfer koşullarına bağlı olarak ilerlediğini göstermektedir. Ray malzemelerinin kimyasal kompozisyonları ve sertlik değerleri R260 kalite için izin verilen aralık içinde bulunmuştur. Teker teması olan bölgeler aşırı plastik deformasyon nedeniyle pekleşmiş ve sertlik değerleri diğer bölgelere göre yüksek çıkmıştır. Yapılan incelemeler sonucunda raylarda aşınma, soyulma ve parça kopması probleminin yuvarlanma temas yorulması (Rolling contract fatigue- RCF) nedeniyle oluştuğu ve çelik yapısında tespit edilen çok sayıda metal dışı kalıntının (inklüzyon) da RCF sırasında oluşan çatlakların ilerlemesini kolaylaştırdığı ve de soyulmalara (shelling) neden olduğu sonucuna varılmıştır. Problemin oluşumunun geciktirilmesi veya önlenmesi için kurb gibi kritik yerlerde daha yüksek dayanımlı rayların kullanılması, kullanılan ray çeliklerinde uluslararası standartlara uygun olarak inklüzyon kontrolü yapılması, teker ve rayların yağlanma ve bakım stratejilerinin gözden geçilmesi, teker-ray temas karakteristiklerinin iyileştirilmesine yönelik çalışmalar yapılması önerilmektedir. Son öneriye yönelik çalı̧̧malar hat ve seyirle ilgili teknik sınırların araç özelliklerine bağlı olarak çıkartılarak sürdürülebilir bir model geliştirilmesini içermektedir.

Anahtar Kelimeler: Ray kusurları, Metalografik inceleme, İçyapı, Yuvarlanma temas yorulması, Soyulma.

\footnotetext{
Sorumlu Yazar: RAYSIMAŞ (Raylı Sistemler Mühendislik ve Müşavirlik A.Ş.), Ankara, Türkiye, ORCID: 0000-0002-8310-8839, augur@anadolu.edu.tr
} 


\title{
Investigation of Caused by Shelling defects on Rail Surface via Metallographic Examination
}

\begin{abstract}
Railways are increasingly used for passenger and freight transportation worldwide. This increased traffic causes more quick and frequent formation of defects on train tracks. In this study, rail sets used in Bursa province, that had been reported to experience rapid wear and scaling, were examined. The rail sets were manufactured from R260 steel and the problem occurs more frequently on curves. For comparison, rail sets from straight lines were also examined. After visual examination, specimens from gauge and field corner regions were taken and prepared for metallographic examination. The microstructure of the specimens was examined under optical and scanning electron (SEM) microscopes. Moreover, Vickers micro-hardness tests were also performed. Micro-chemical analyses were performed using an energy dispersive X-ray spectroscopy (EDS) system attached to the SEM. For macro-chemical analysis, an optical emission spectrometer (OES) was used. The cross section of the rails was macro-etched for macro-examination. The results show that the microstructure of the rails is composed of $100 \%$ pearlite. On the other hand, the pearlitic structure degenerates at parts of the rail which are under loading. Due to severe plastic deformation, the pearlitic structure changes into a fiber-like structure composed of sub-micron ferrite and cementite. Those degenerated pearlitic regions have higher hardness due to strain hardening and cause crack initiation. Those cracks can then grow into inner sections of the rail easily due to the presence of non-metallic inclusions in the microstructure. Iron oxide particles were found in the vicinity of cracks; which indicate that cracks do not grow rapidly, they rather grow in time according to usage and atmospheric conditions. The examinations revealed that the wear, cracks and scaling problems were formed due to rolling contact fatigue (RCF). The presence of inclusions enhanced the growth of RCF-cracks and later cause "shelling". In order to delay or prevent this problem, using higher strength rails at critical locations such as curves, controlling and rating the non-metallic inclusions in accordance with the international standards, checking the lubrication and maintenance strategies of rails and wheels, working on optimization of rail-wheel contact characteristics are recommended. The last recommendation involves developing a sustainable model by identifying technical limitations of the line and cruise depending on vehicle characteristics.
\end{abstract}

Keywords: Rail defects, Metallographic examination, Microstructure, Rolling contact fatigue (RCF), Shelling.

\section{Giriș}

Yolcu ve yük taşımacılığında güvenli, hızlı ve uygun maliyetli olarak demiryolu yatırımları ekonominin itici gücü olarak dünya çapında artarak gelişme göstermektedir [1]. Küresel talep ve demiryolu ağlarının kullanımındaki artış, toplam yük/yolcu kapasitesinin artması ile aks ağırlıklarında ve tren hızlarında artışı beraberinde getirmektedir [2, 3]. Bu da kaçınılmaz olarak ray bileşenlerinin ömründe azalmaya ve ray bakım maliyetlerinde artışa yol açmaktadır [4-6]. Artan ray tekerlek temas döngüleri, aşınma ve yorgunluk kusurlarının daha hızlı ve daha sık görülmesi ile servis ömrünün azalması tren işletilmesinde riski arttıran önemli bir faktördür [7-9]. Tekerlek ray arası temas gerilmeleri, kalıntı gerilmelerin etkisi altında, düşey gerilme, eksen bükülmesi veya termal gerilme oluşturabilir ve ray kusurlarının meydana gelmesini, geliştirebilir. Tekerlek ve ray geometrisinden etkilenen bu kuvvetler aşınma özelliklerine ve çelik raylara bağlıdır [10-12]. Sürdürülebilir olarak demiryolu hatlarının gelişimi ve güvenliğinin sağlanması kullanılan bileşenlerin yorulma $[13,14]$ ömürlerinin aktif bir şekilde denetlenmesini önemli hale getirmiştir. Yaşam/servis ömrü belirlenirken hattın en önemli bileşeni olan ray ömrü esas alınmaktadır [15]. Malzeme dayanıklılığı, sağlamlılığı dört ana faktörden etkilenir; yükleme, tasarım, imalat ve malzeme seçimi, bu faktörlerin entegrasyonu, bileşenin/bileşenlerin yorulma mukavemetini etkiler [16]. Demiryolu standardları çerçevesinde sayısal ölçme ve değerlendirme yöntemleri ile hat ve komponentlerin periyodik olarak uygunluğunun kontrolü olası problemlerin giderilmesi yönünde hayati önem taşımaktadır. Farklı yaklaşımlarla raylardaki bozunma; ray yapısı (Ray yapısal parametreleri arasında balast tipi, ped sertliği ve ray tipi bulunur), hat geometrisi (Hat geometrik parametreleri traverslar arası mesafe, drenaj şartları ve hat kalitesi endeksleridir), ve trafik parametreleri (tonaj, tren hızı, aks yükleri, yük çevrimleri), ray altyapısı (balast ve ray alt katmanları yerleşimi), ray üstyapısı, ray geometrisi incelenebilmektedir [17].

Ray-tekerlek temas gerilimleri; düşey yük, enine ve boyuna sürünme kuvvetleri, ray yüksekliği boyunca yük kaynaklı sıkıştırma ve boşaltma nedenli uzunlamasına kalıntı gerilmeleridir. Temas bölgesindeki gerilimler malzeme mikro yapısında istenmeyen kusurların doğmasına sebep olmaktadır [18].

Malzeme bünyesinde gerilim kaynaklı değişimlerin tane yapısında değişimler oluşturması ve malzeme dayanımına etkisi çeşitli metalografik inceleme ve mikro-kimyasal analizlerinin yapılması ile tayin edilebilmektedir [19]. Güvenli sürüş açısından demiryolu ray hata nedenlerinin belirlenmesi tahribatsız muayene yöntemleri ile yapılabilmektedir [20]. Maliyetli olsa da hızlı ve doğruluk oranı yüksek bir biçimde ray çatlak tipleri görüntü işleme tabanlı ve diğer yöntemlerle tespit edilebilmektedir [21, 22].

Demiryolu uygulamalarında yaygın olarak ana-yapısı perlit olan ray çelikleri kullanılmaktadır [15, 23]. Yuvarlanma temas yorulmasına (RCF), kabuklanma ve soyulma problemlerine demiryolu endüstrisinde yaygın olan rastlanılmaktadır. Tekerlekler ve raylar arasındaki yuvarlanma temasından tekrarlanan yüklerin uygulanması, malzemenin en üst katmanında ciddi plastik deformasyona [24] neden olur, bu da sonunda yorgunluk hasarı bir sınırı aştığında çatlak oluşumuna yol açar [25]. RCF ve aşınma arasında optimum çözümlerin bulunmasında ray teker malzemelerinin mikroyapı kararlılığının sağlanması çatlakların önlenmesi için önemlidir [26-28].

Bu çalışmada Bursa ilinde kullanılan R260 kalite ray çeliklerinde meydana gelen soyulma ve kopmaların kök nedenini tespit etmek üzere yapılan metalografik inceleme, kimyasal analiz ve sertlik testleri sonuçları sunulmuştur. Kurp çapı 250m veya daha küçük olan ve düz hat (aliyman) bölgelerinden alınan ray numunelerin kusurları Uluslarası Demiryolları Birliği (UIC) 712 R kodlu ray kusurları [29], tahribatsız ray muayeneleri manueli [30], ray kusurları el kitabı [31] ve sertlik değerleri EN 13674-1'e göre tespit edilmiştir. Kullanılan malzemenin uygunluğu kimyasal kompozisyon ve sertlik yönünden incelenmiş, kısa sürede aşınma ve kopma probleminin kök nedeninin belirlenerek, problemin çözümüne yönelik yapılması gerekenler belirlenmiştir. 
Tablo 1. Hafif raylı sistem (HRS) araç teknik özellikleri

\begin{tabular}{|c|c|c|c|}
\hline HRS Araçları Teknik Verilerinin Karşılaştırılması & $\mathbf{A}$ & B & $\mathbf{C}$ \\
\hline Aracın kuplaj üzerinden uzunluğu (mm) & 27.770 & 28.140 & 28.000 \\
\hline Araç genişliği $(\mathrm{mm})$ & 2.650 & 2.650 & 2.650 \\
\hline Araç yüksekliği (Çatı ekipmanları dahil) (mm) & 3.800 & 3.750 & 3.800 \\
\hline Yüksüz araç ağırlı̆̆ı, maks. (Ton) & 40,04 & 39,0 & 41,0 \\
\hline Yüklü araç ăgırlı̆ğ (Ton) & 59,09 & 61,0 & 62 \\
\hline İzin verilen dingil ağırlı̆̆l, maks. $3 / 3$ yüklü iken (Ton) & 9,98 & 12,0 & 10,8 \\
\hline Motor çekiş gücü $(\mathrm{kW})$ & $4 \times 140$ & $4 \times 125$ & $4 \times 140$ \\
\hline Huzlanma ivmesi (2/3 yükte $35 \mathrm{~km} / \mathrm{sa}^{\prime} \mathrm{e}$ kadar $)\left(\mathrm{m} / \mathrm{s}^{2}\right)$ & 1,2 & 1,3 & 1,2 \\
\hline Frenleme ivmesi $\left(80 \mathrm{~km} / \mathrm{h}^{\prime}\right.$ ten $)\left(\mathrm{m} / \mathrm{s}^{2}\right)$ & $1,3 / 1,22$ & $1,4 / 1,3$ & 1,3 \\
\hline Acil frenleme ivmesi $\left(2 / 3\right.$ yükte) $\left(\mathrm{m} / \mathrm{s}^{2}\right)$ & $3,22 / 2,75$ & $3,4 / 2,9$ & 2,8 \\
\hline Dingil açıklığı $(\mathrm{mm})$ & 1.900 & 1.900 & 2.100 \\
\hline Tekerlek genişliği $(\mathrm{mm})$ & 135 & 135 & 135 \\
\hline Minimum yatay kurp yarıçapı $(\mathrm{m})$ & \multicolumn{3}{|c|}{ Depoda 50 cari hatta 110} \\
\hline Asgari içbükey / dışbükey yarıçapı (m) & $>500$ & $>500$ & $>300$ \\
\hline
\end{tabular}

\section{Malzeme, Ön Bilgiler ve Deneysel Çalışmalar}

\subsection{Malzeme ve Ön Bilgiler}

Teslim edilen ray parçaları ve aşınma problemi gözlemlenen kurp bölgesinin görüntüleri Şekil 1'de ve düz hat bölgesinin görüntüleri Şekil 2'de verilmiştir. Problem hakkındaki ön bilgiler; kullanımı sırasında beklenenden kısa sürede aşınarak üzerinden parçaların kopmaya başladığı ray parçaları R260 kalite çelikten imal edilmiştir. Aşınma ve parça kopma problemi kurplarda ve ray kesitinin mantar bölgesinin yanak yüzeylerinde, özellikle tekerin temas ettiği diğer raya bakan yanak yüzeyinde ağırlıklı olarak gerçekleştiği gözlemlenmiştir. Aşınmanın ağırlıklı gözlemlendiği bölgeler Şekil 3'de ayrıca gösterilmiştir. Raylar üzerinde seyahat eden vagon setlerinin teknik özellikleri Tablo 1'de verilmiştir. Problem artan hat trafiği ve daha ağır olan C-tipi vagon setlerinin devreye alınması ile birlikte daha sık gözlemlenmeye başlamıştır. Problem nedeniyle önce sürüş konforu düşmekte ve problemin (aşınmanın) ilerlemesi nedeniyle raylar beklenenden daha kısa sürede taşlama (grinding) işlemine alınmakta ve sonrasında da kullanılamaz hale gelerek komple değişimi yapılmaktadır.
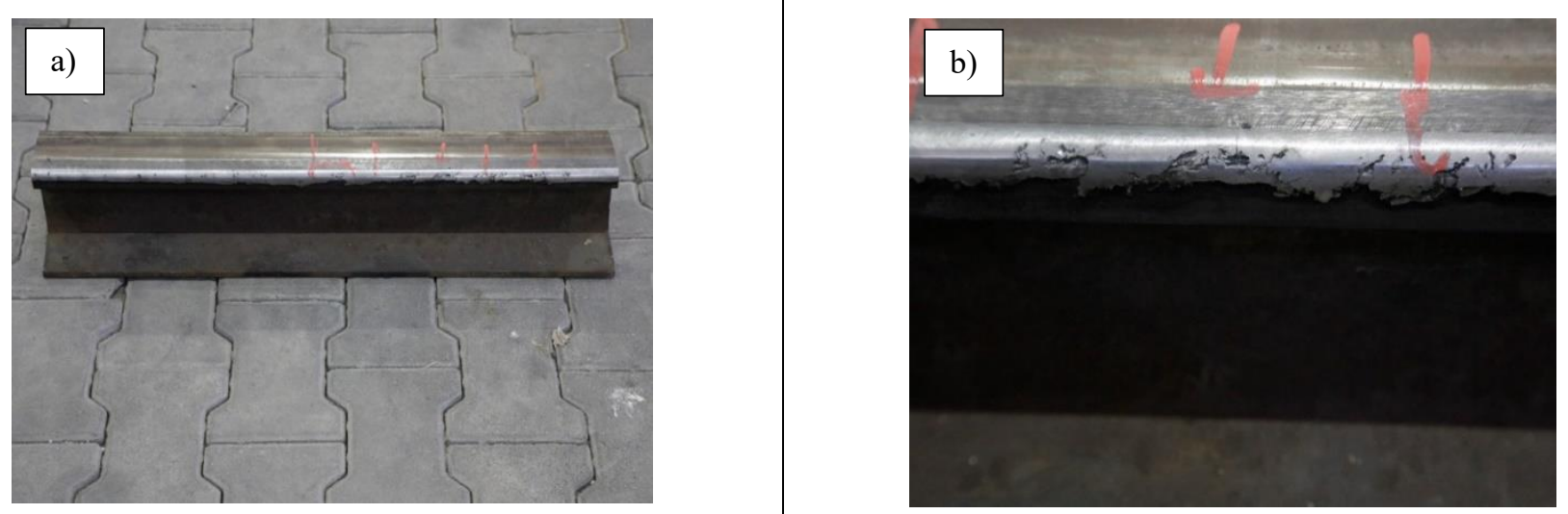

Şekil 1. Kurp bölgesi a) Aşınan ve Parça Kopan Ray parçası, b) Mantar bölgesi yanak (gauge) yüzeyinde aşınma detayı 


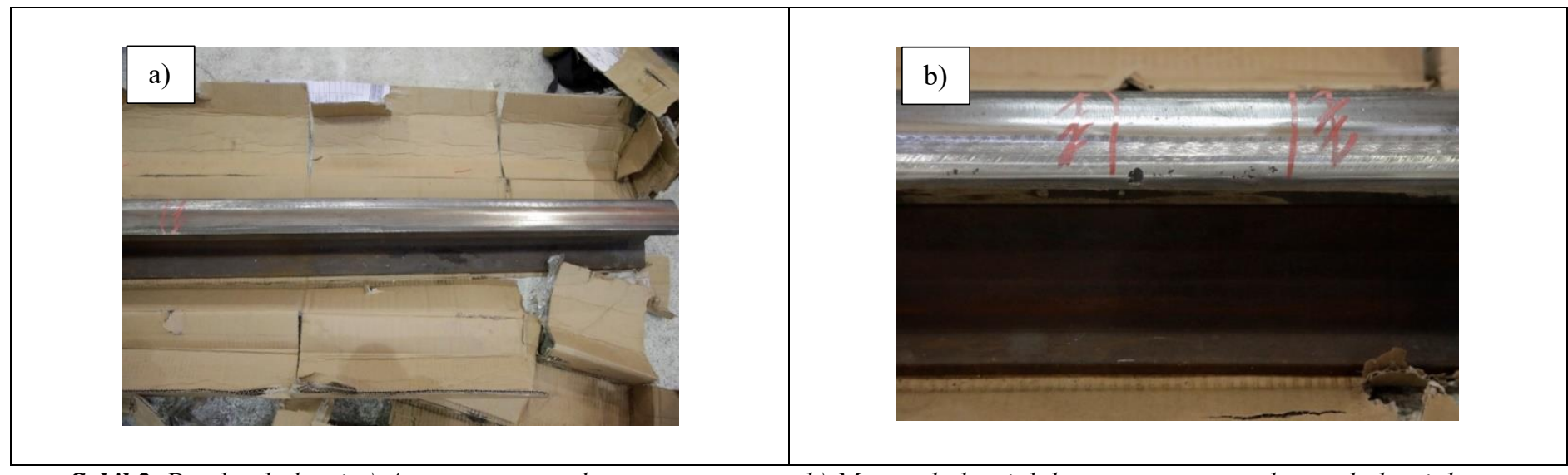

Şekil 2. Düz hat bölgesi a) Aşınan ve parça kopan ray parçası, b) Mantar bölgesi daha az aşınan yuvarlanma bölgesi detayl

Metalografik inceleme için numune çıkarılan bölgeler Şekil 3’te verilmiştir. Diğer bir gösterimle ray tekerlek arası temas bölgeleri; A: Yuvarlanma yüzeyi, B: Yanak (gauge) bölgesi, C: Yanak (field corner) şeklinde tanımlanmıştır [9]. Karşılaştırma yapilabilmesi amacıyla ray kesitinin mantar bölgesi üzerinde yer alan yuvarlanma yüzeyinden ve teker teması olmayan diğer yanak yüzeyinden de numuneler çıkarılmıştır.

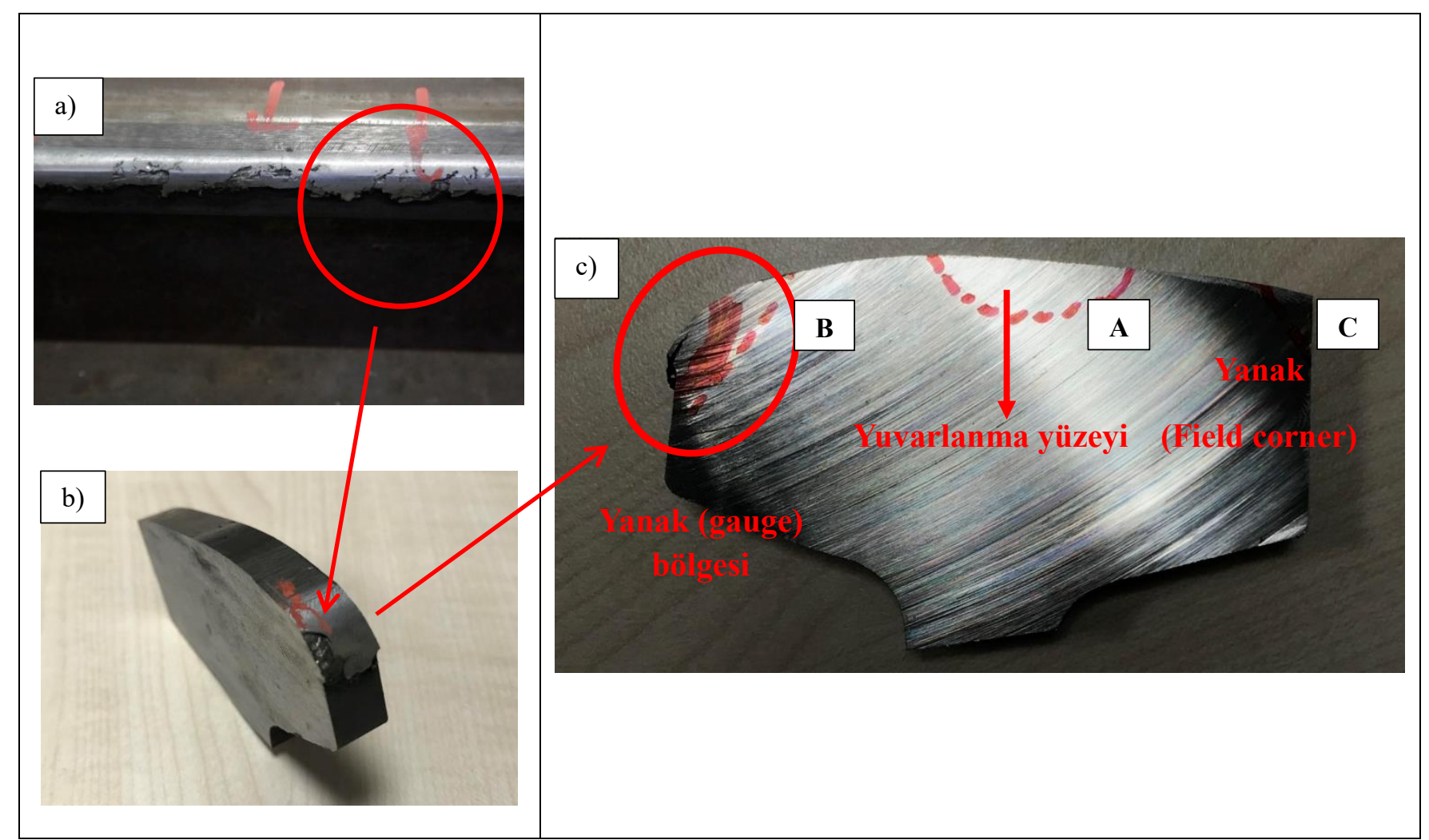

Şekil 3. Metalografik inceleme için numune çıkarlan bölgeler a) Enine kesit alınan ray bölgesi (yanak- gauge bölgesi) b) Mantar bölgesi ve aşınma detayl, c) Ray mantar bölgesi kesiti üzerinde metalografik inceleme için numune çıkarılan bölgeler

\subsection{Deneysel Çalışmalar}

Deneysel çalışmalara normalden (eskisinden) daha hızlı aşındığı belirtilen aşınan ve parça kopan ray parçalarının aşınma yüzeyleri gözle ön inceleme yapılarak başlanmıştır. Her iki yanak ve yuvarlanma yolu üzerinden parçalar çıkarılarak metalografik inceleme yapılmış ve sertlik testleri gerçekleştirilmiştir. Ray enine kesitinde $\% 5$ Nital (5 cc nitrik asit ve $95 \mathrm{cc}$ saf su) solüsyonuyla makrodağlanmış ve kesit genel yapısına bakılarak makro-inceleme gerçekleştirildi. Sonrasında mikro yapı incelemeleri, mikro- (SEM-EDS) ve makro-kimyasal (optik emisyon spektrometresi) analizler, ve sertlik testleri gerçekleştirilmiştir.

\subsubsection{Mikroyapt Íncelemesi}

Metalografik inceleme için Şekil 3'de belirtilen bölgelerden alınan numuneler SiC zımpara kâğıdı ile kaba ve ince zımparalamadan (320 ve 500 grit) geçirildikten sonra elmas parlatma solüsyonları ile 3 aşamalı parlatma ( $9 \mu \mathrm{m} 3 \mu \mathrm{m}-1 \mu \mathrm{m}$ basamakları) yapılmıştır. Zımparalama ve parlatmalar Struers Tegramin-25 cihazı kullanılarak gerçekleştirilmiştir. Parlatılan yüzeyler \%2 Nital (2 cc Nitrik asit ve $98 \mathrm{cc}$ etanol) ve pikral (4 gr pikrik asit ve $100 \mathrm{cc}$ etanol) solüsyonları kullanılarak dağlanmıştır. Takip edilen numune hazırlama prosedürü ASTM E3 standardına uygun yapılmıştır. Metalografik inceleme için hazırlanan numune yüzeyleri Nikon Eclipse LV 150 
optik mikroskop ve Clemex Vision PE® görüntü analiz sistemi kullanılarak incelenmiştir. Numune yüzeyleri aydınlık alan aydınlatması altında 50x, 100x, 200x, 500x ve 1000x büyütmelerde incelenmiş ve “temsili”" bölgelerinden içyapı görüntüleri alınmıştır. Zeiss Merlin taramalı elektron mikroskobu (SEM) kullanılarak numunelerin içyapıları daha yüksek çözünürlükte ve yüksek büyütmelerde incelenmiştir. SEM incelemeleri sırasında $15 \mathrm{kV}$ ivmelendirme voltajı altında 500x ile 7500x büyütme aralığında ikincil elektron ve geri saçılan elektron dedektörleri kullanılarak içyapı görüntüleri alınmıştır.

\subsubsection{SEM-EDS ile Mikro-Kimyasal Analiz}

Metalografik inceleme için hazırlanan numuneler üzerinde SEM'e bağlı EDAX Pegasus EDS sistemi yardımıyla mikro-kimyasal analizler gerçekleştirilmiştir. Spektrumlar $15 \mathrm{kV}$ ivmelendirme voltajı altında, 6,0 nA demet akımı kullanılarak dedektörün canlı kaldığ 1 $19 \mathrm{~s}$ boyunca toplanmıştır. X-1şınları 7,68 $\mu$ s sinyal işleme süresi kullanılarak sayılmıştır.

\subsubsection{Makro-Kimyasal Analiz}

Taşlanmış numune yüzeylerine Bruker Tasman Q4 optik emisyon spektrometresi ile toplam 10 yakım yapılarak genel kimyasal kompozisyonları tespit edilmiştir.

\subsubsection{Sertlik Testleri}

Tüm numunelerin yüzeylerine Zwick ZHV-10 cihazı kullanılarak 200 gr yükle Vickers ucun (indentör) 25 mm/dak hızda batırılmasıyla oluşturulan izin 40x büyütme yapan bir objektif lens yardımıyla görüntülenip ölçülmesiyle sertlik testi yapılmıştır. Metalografik inceleme için hazırlanan numune yüzeyleri üzerinde rastgele seçilen, numune başına 10 farklı bölgeden alınan sertlik değerlerinin ortalaması alınarak her numune için Vickers sertlik değerleri HV 0,2 cinsinden belirlenmiş ve ASTM E140’a göre Brinell cinsine çevrilmiştir.

\section{Sonuçlar}

\subsection{Optik Mikroskop Görüntüleri (Parlatılmış numune)}

Raydan çıkarılan numunelerin parlatılmış haldeki içyapı görüntüleri (Şekil 4-6), numunelerde bazı metal dışı kalıntılar (inklüzyon) gri ve siyah noktalar şeklinde görülmektedir. Bu inklüzyonların büyük çoğunluğu 10 mikron altı boyutlardadır ve sayıca fazla inklüzyon vardır. Bu inklüzyonlar aşırı deformasyon nedeniyle oluşan çatlakların ray kesiti içine ilerlemesini kolaylaştırmaktadırlar.

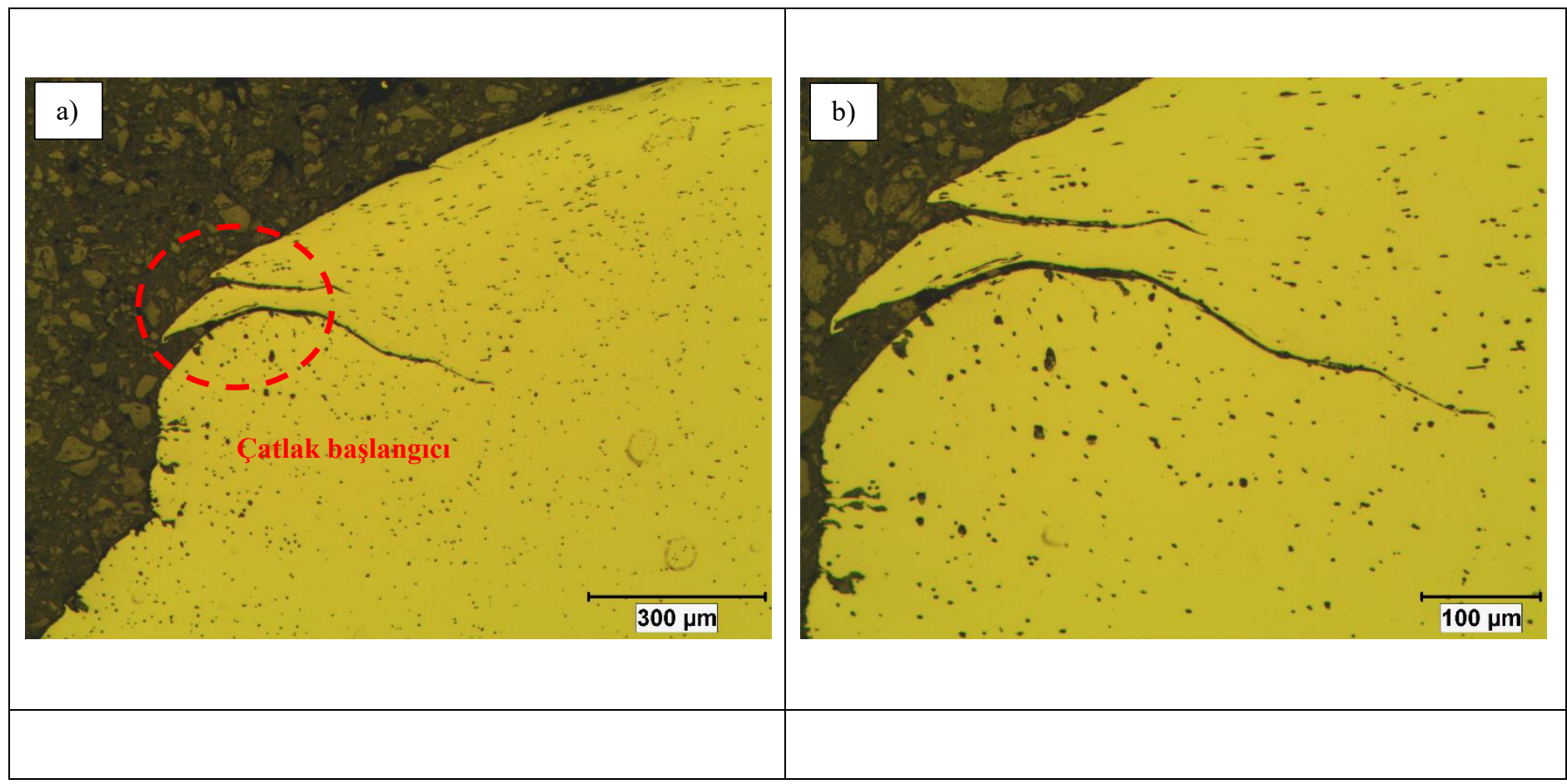




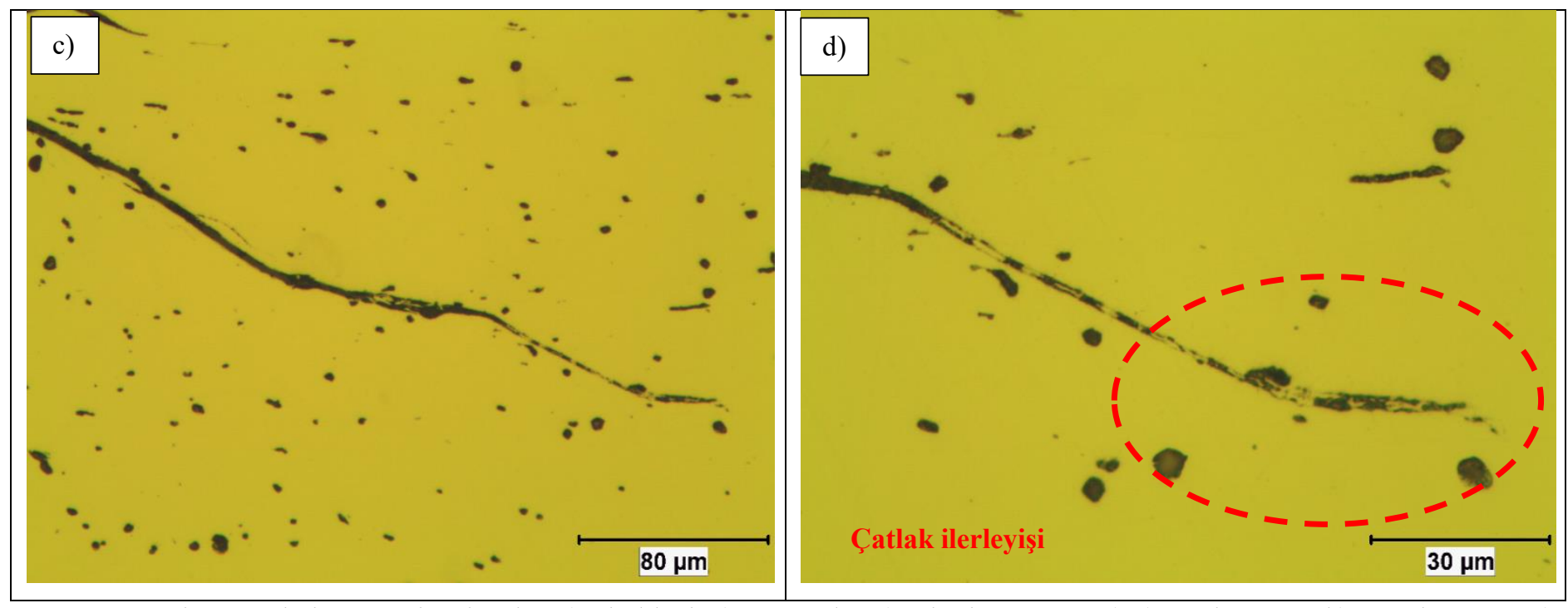

Şekil 4. Yanak-gauge bölgesi optik mikroskop (aydınlık alan) görüntüleri (parlatılmış numune) a) 50x büyütme, b) 100x büyütme, c) 200x büyütme, d) 500x büyütme

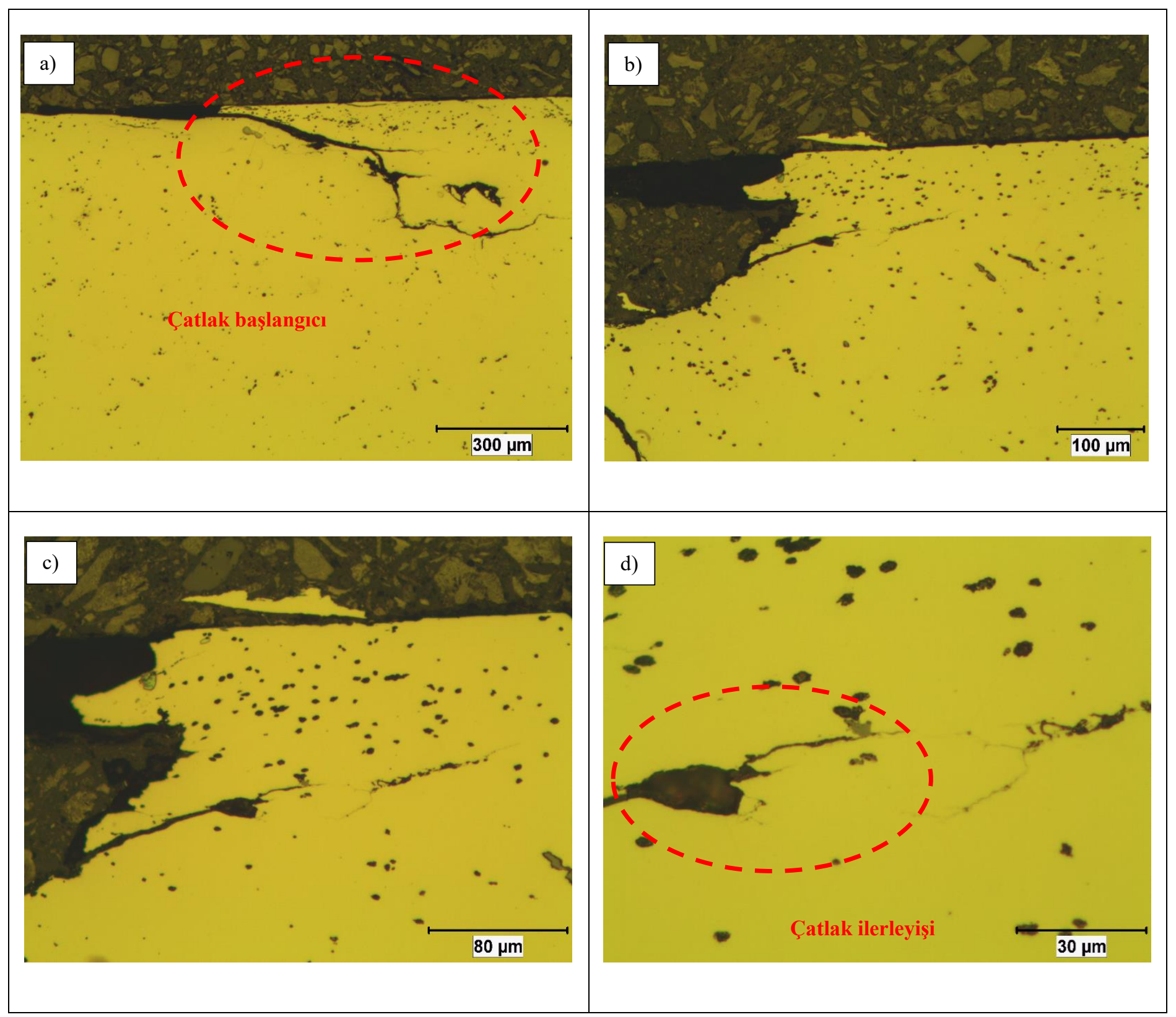

Şekil 5. Yuvarlanma yüzeyi bölgesi optik mikroskop (aydınlık alan) görüntüleri (parlatılmış numune) a) 50x büyütme b) 100x 


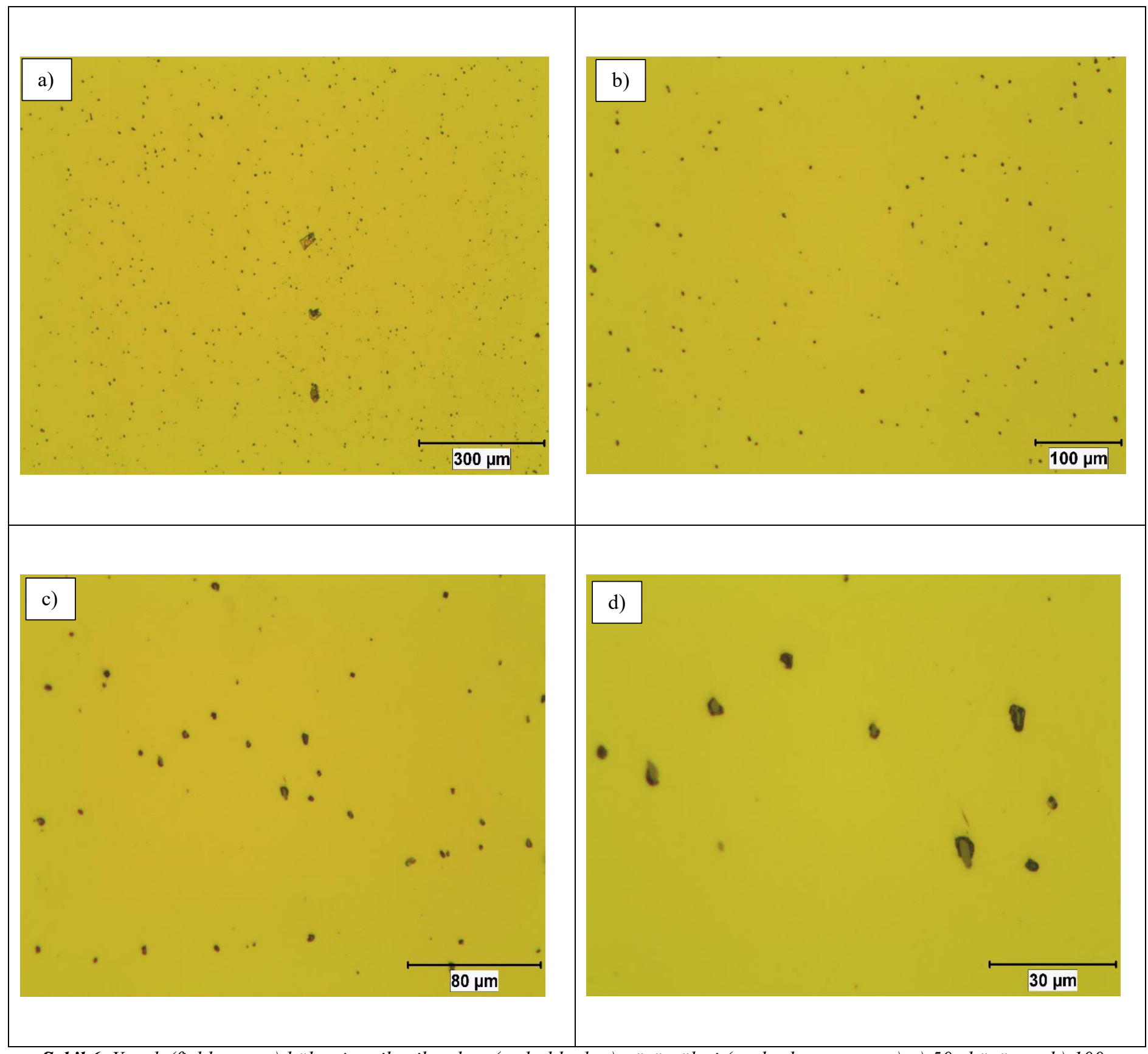

Şekil 6. Yanak (field corner) bölgesi optik mikroskop (aydınlık alan) görüntüleri (parlatılmış numune) a) 50x büyütme, b) 100x büyütme, c) 200x büyütme, d) 500x büyütme

\subsection{Optik Mikroskop Görüntüleri (Dağlanmış numune)}

Raydan çıkarılan numunelerin dağlanmış haldeki içyapı görüntüleri Şekil 7-9'da verilmiştir. Yapılan metalografik inceleme sonucunda ray parçaların ana-yapısının neredeyse $\% 100$ perlit olduğu gözlemlenmiştir. Teker temasının ve buna bağlı olarak aşınmanın asgari düzeyde olduğu yanak (field corner) bölgesinde yapı tamamen ince lamel yapıda perlitten oluşmaktadır (Şekil 9).

Demiryolu hatlarında uygulamada, ferrit-perlit çelikleri, yüksek mukavemetleri nedeniyle ve mükemmel aşınma direnci ile birlikte kullanılmaktadır. Perlitik çeliğin hasar toleransı davranışı birçok çalışmada bir eleştiri noktası olmuştur. Perlitik çelik beynitik ray çeliği ile karşılaştırıldığında, yorulma çatlağı büyümesine direnç daha düşük iken, kırılma tokluğuda düşüktür. Perlitik çeliğin düşük kırılma tokluğu, gevrek kırılma yüzeyinin özellikleri ile ilişkilidir. Yorulma çatlağı ilerleme davranışı perlitik yapı içindeki ara katman boşlukları ve inklüzyon kaynaklıdır $[12,15]$.

Rayların mantar bölgesi üzerinde yer alan yuvarlanma yolu bölgesinde de yanak-gauge bölgesine benzer şekilde aşırı deforme olarak bozulmaya başlamış perlitik yapı gözlemlenmiştir (Şekil 7-8). Bu bölgede de çatlaklar oluşup iç kısımlara doğru ilerlemiştir. Öte yandan yanak-gauge bölgesinden farklı olarak temel yüklerin basma tipi olması ve çatlakların malzeme içine doğru ilerliyor olması yanak yüzeyindeki kadar kritik aşınmaları ve parça kopmalarını ciddi oranda azaltmıştır. Aşınma gözlemlenmeyen diğer yanak bölgesinin mikroyapısı Şekil 9'da verilmiştir. Bu bölgede ince lamelli perlitik yapı gözlemlenmektedir. Bu bölgede yapı deforme olmamış ve bozulmaya uğramamıştır. 


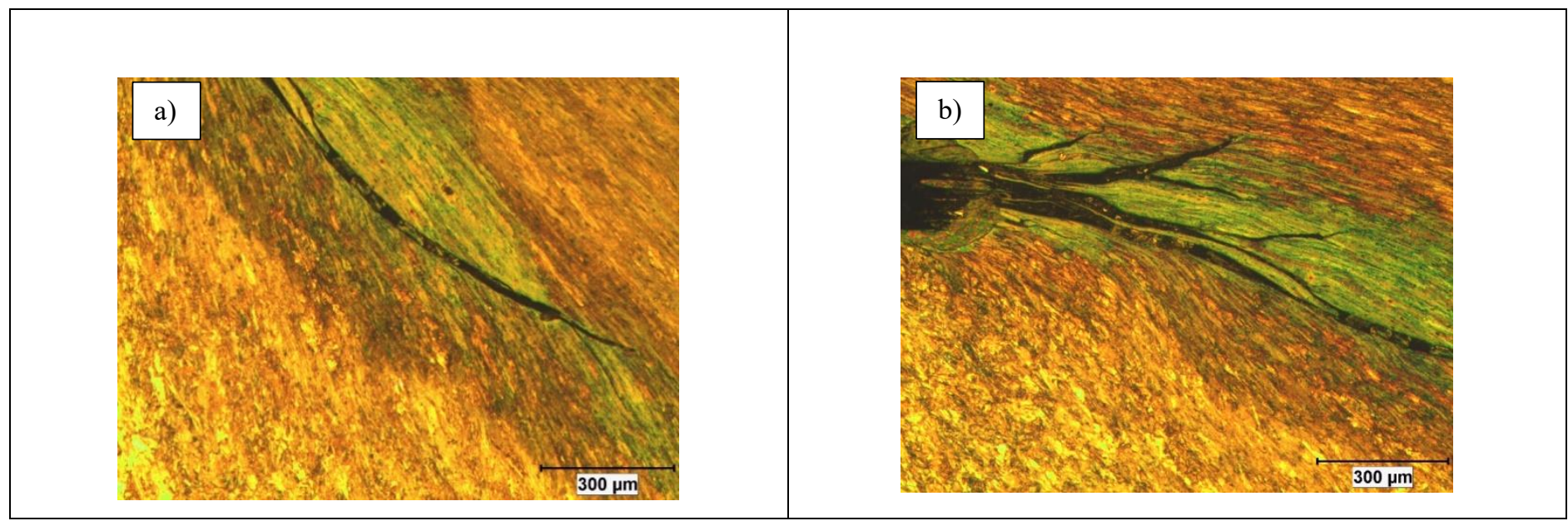

Şekil 7. Yanak (gauge) bölgesi optik mikroskop (aydınlık alan) ) görüntüleri (dağlanmış numune) a), b) 50x büyütme

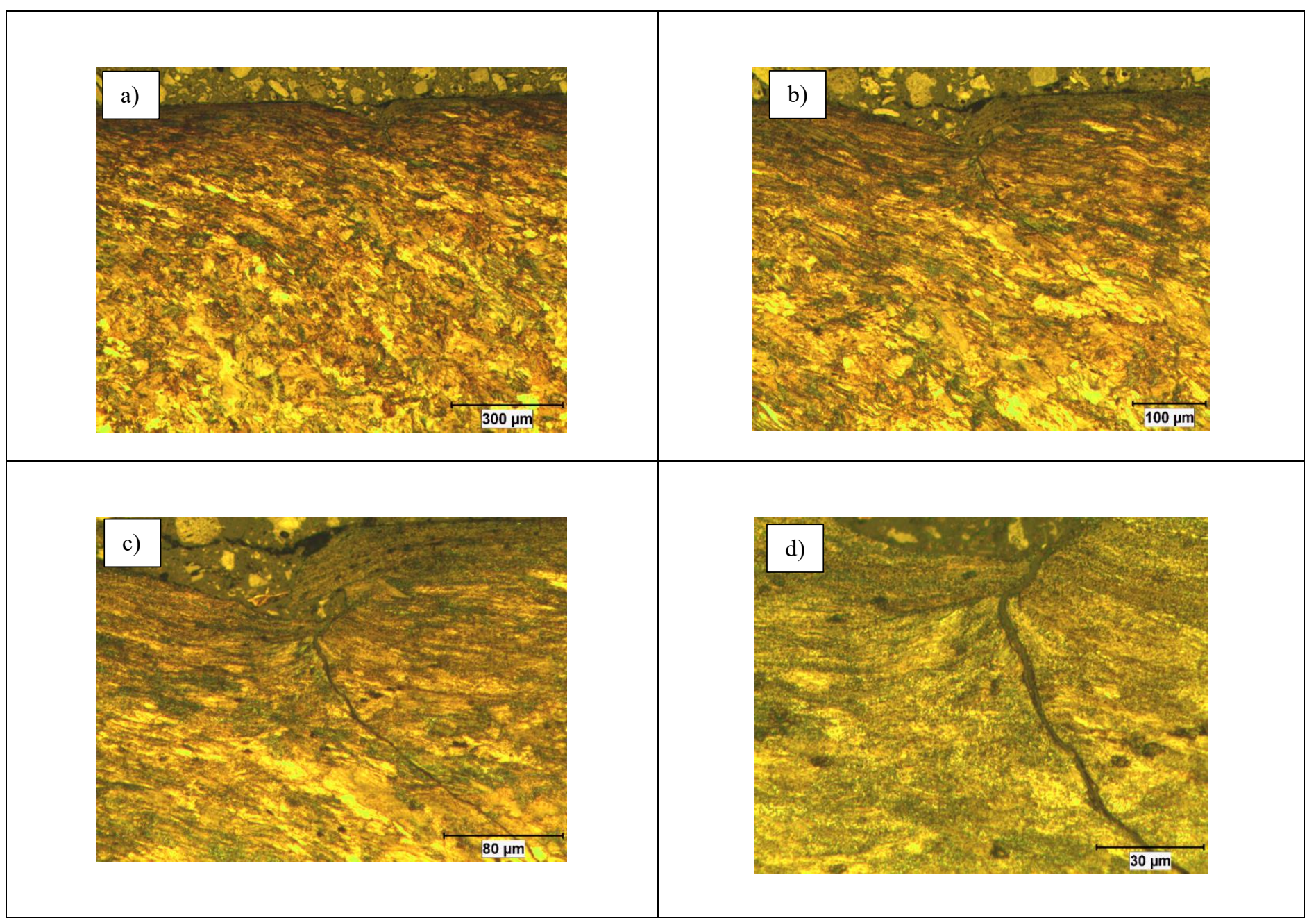

Şekil 8. Yuvarlanma yolu bölgesi optik mikroskop (aydınlık alan) görüntüleri (dağlanmış numune) a) 50x büyütme, b) 100x büyütme, c) $200 x$ büyütme, d) 500x büyütme 


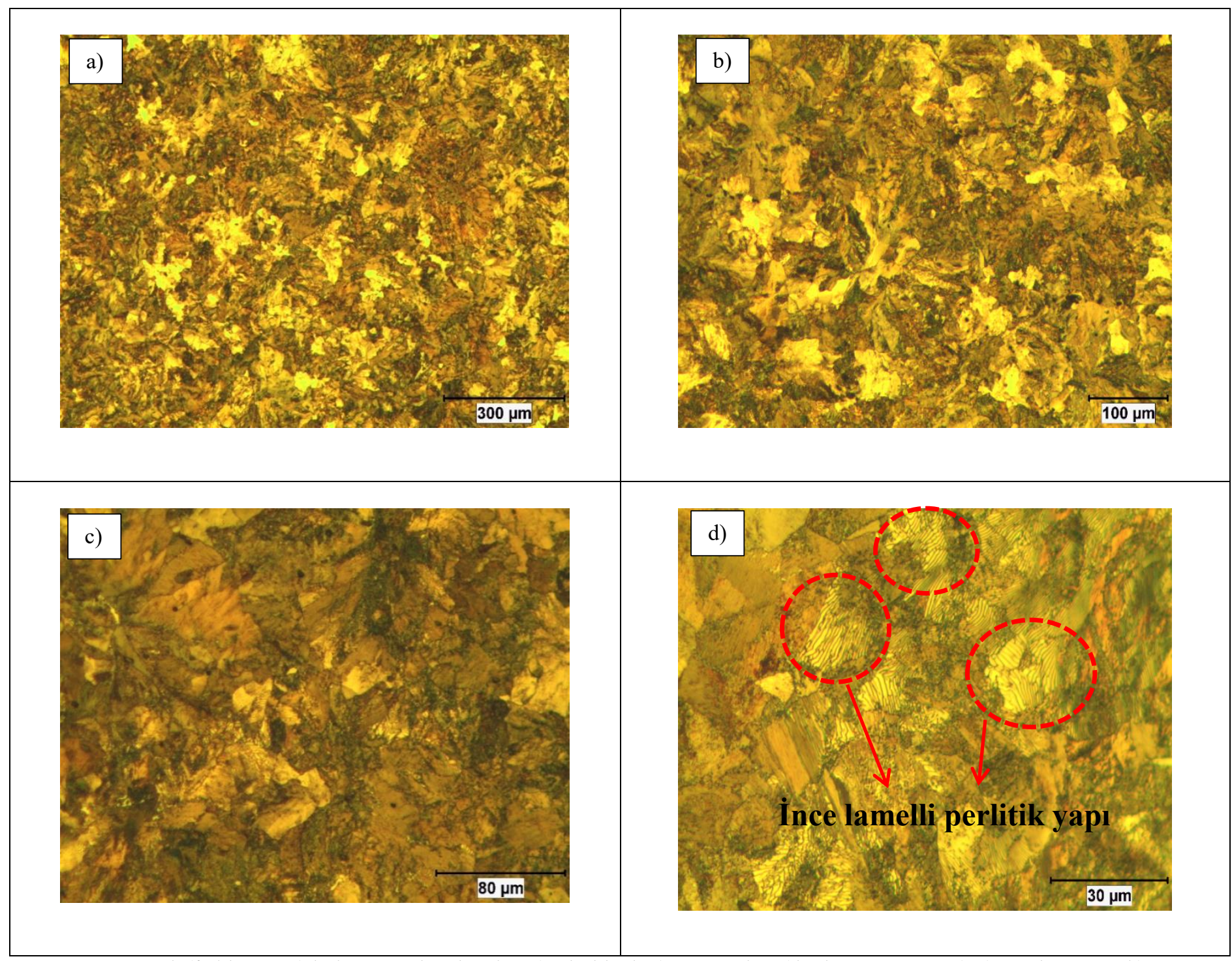

Şekil 9. Yanak (field corner) bölgesi optik mikroskop (aydınlık alan) görüntüleri (dağlanmış numune) a) 50x büyütme, b) $100 x$ büyütme, c) 200x büyütme, d) 500x büyütme

\subsection{Taramalı Elektron Mikroskobu (SEM) İncelemeleri}

Özellikle kurplarda teker temasının arttığı, yanak-gauge bölgesinde ise aşınma olan yerlerde aşırı deforme olmuş, lamel yapının bozularak mikron-altı büyüklükte ferrit ve sementit dönüştüğü gözlemlenmiştir (Şekil 10). Şekil 10.b, c, d'de görülen lifli katmanlar ferrit bölgelerini dışındaki beyaz noktalar ise sementit bölgelerini göstermektedir. Așırı deforme olan yapıda çatlaklar oluşmuş ve daha az deforme olan bölgeyle aşırı deforme olan bölge arasında malzeme içlerine doğru ilerlemiştir. Ray tekerlek arayüz el kitabında akışkanın (örneğin yağmur suyu) mevcut çatlak bölgesine girmesi ile çatlak üzerindeki yük hareketleri değişimi ile çatlağın ilerlediği belirtilmiştir [9,32]. Çatlak ilerledikten sonra malzeme yüzeyinden parça kopmalarına da neden olmuştur. Bu noktada tekerle ray kesiti teması neticesinde yanak-gauge bölgesinde oluşan kesme tipi gerilimler de parça kopmalarını kolaylaştırmıştır.

Rayların mantar bölgesi üzerinde yer alan yuvarlanma yolu bölgesinde de yanak-gauge bölgesine benzer şekilde aşırı deforme olarak bozulmaya başlamış perlitik yapı gözlemlenmiştir (Şekil 10-11). Bu bölgede de çatlaklar oluşup iç kısımlara doğru ilerlemiş̧ir. Öte yandan yanak-gauge bölgesinden farklı olarak temel yüklerin basma tipi olması ve çatlakların malzeme içine doğru ilerliyor olması yanak yüzeyindeki kadar kritik aşınmaları ve parça kopmalarını ciddi oranda azaltııışır.

Yuvarlanma yolu bölgesinde gözlemlenen çatlakların üzerinde SEM-EDS sistemi ile yapılan noktasal mikro-kimyasal analizlerde (Şekil 11) demir oksit (FeO) bulunmuştur. Bu durum çatlakların aniden değil, zaman içinde kullanıma ve atmosfer koşullarına bağlı olarak ilerlediğini ve çatlak ilerleyene kadar, çatlağın yüzeylerinin oksitlendiğini göstermektedir. 


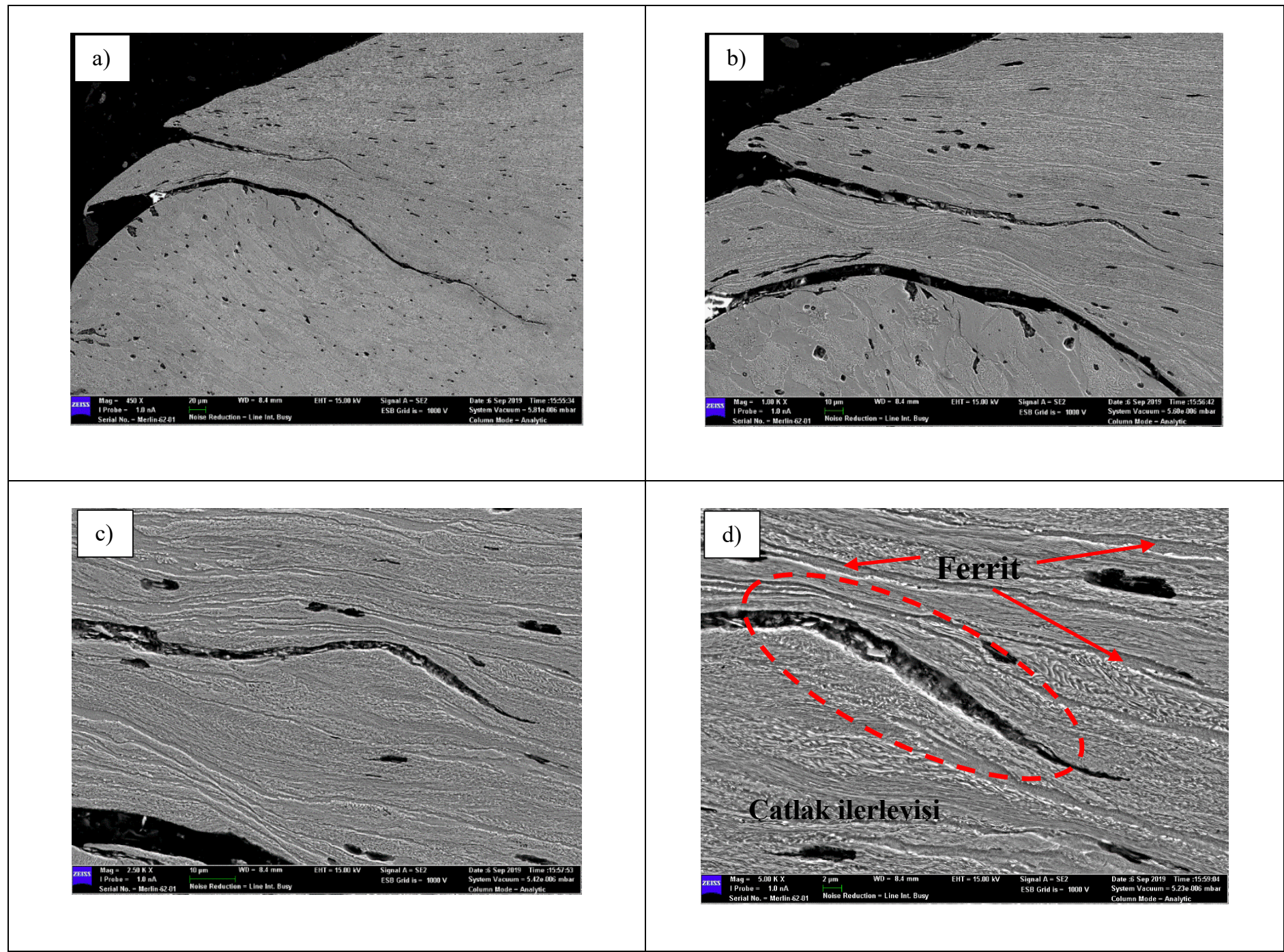

Şekil 10. Yanak-gauge bölgesi SEM görüntüleri (ikincil elektron dedektörü) a) 450x büyütme, b) 1000x büyütme, c) 2500x büyütme, d) 5000x büyütme

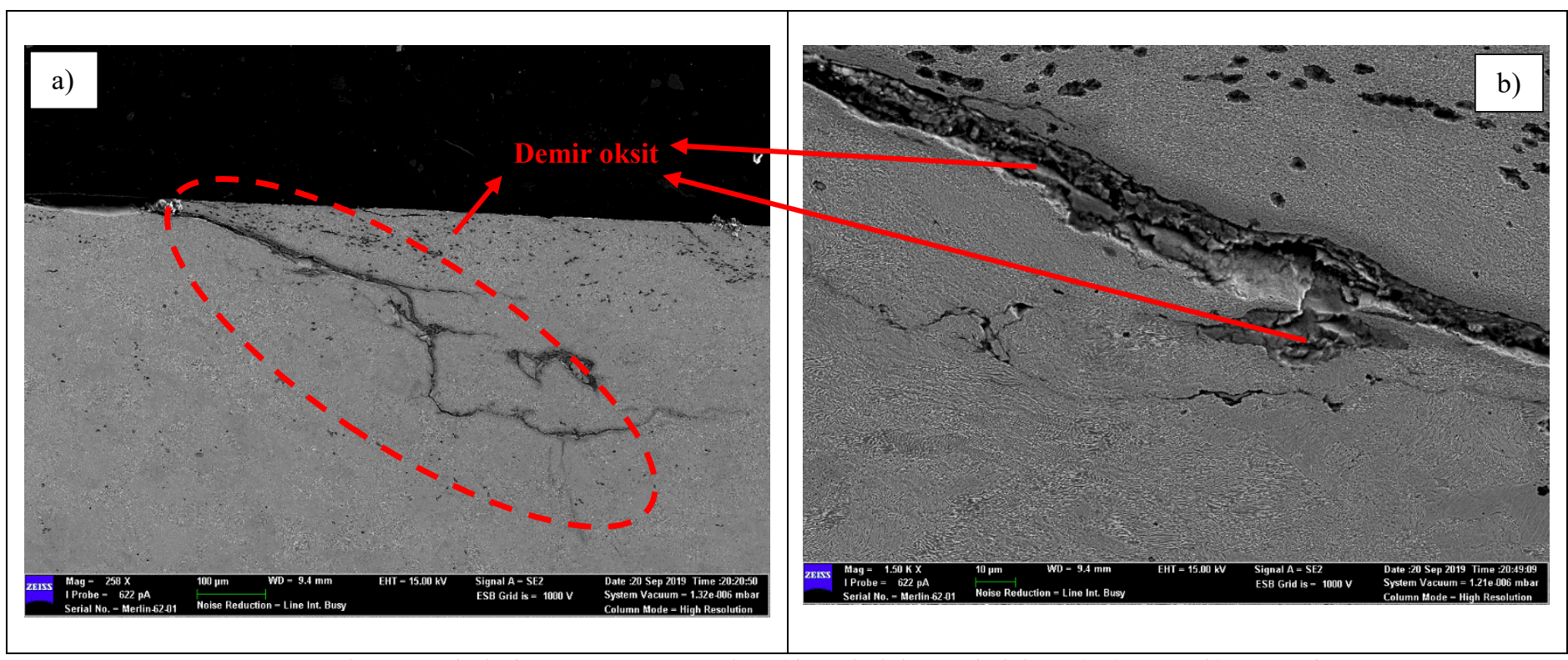

Şekil 11. Yuvarlanma yolu bölgesi SEM görüntüleri (ikincil elektron dedektörü) a) 250x, b) 1500x büyütme

Yanak (field corner) bölgesindeki ince lamel yapının detayları daha yüksek büyütmeli Şekil 12’teki SEM fotoğraflarında gözükmektedir. Eser miktarda ötektoid öncesi dönüşüm sırasında oluşan ferrit bölgeleri de mevcuttur. 


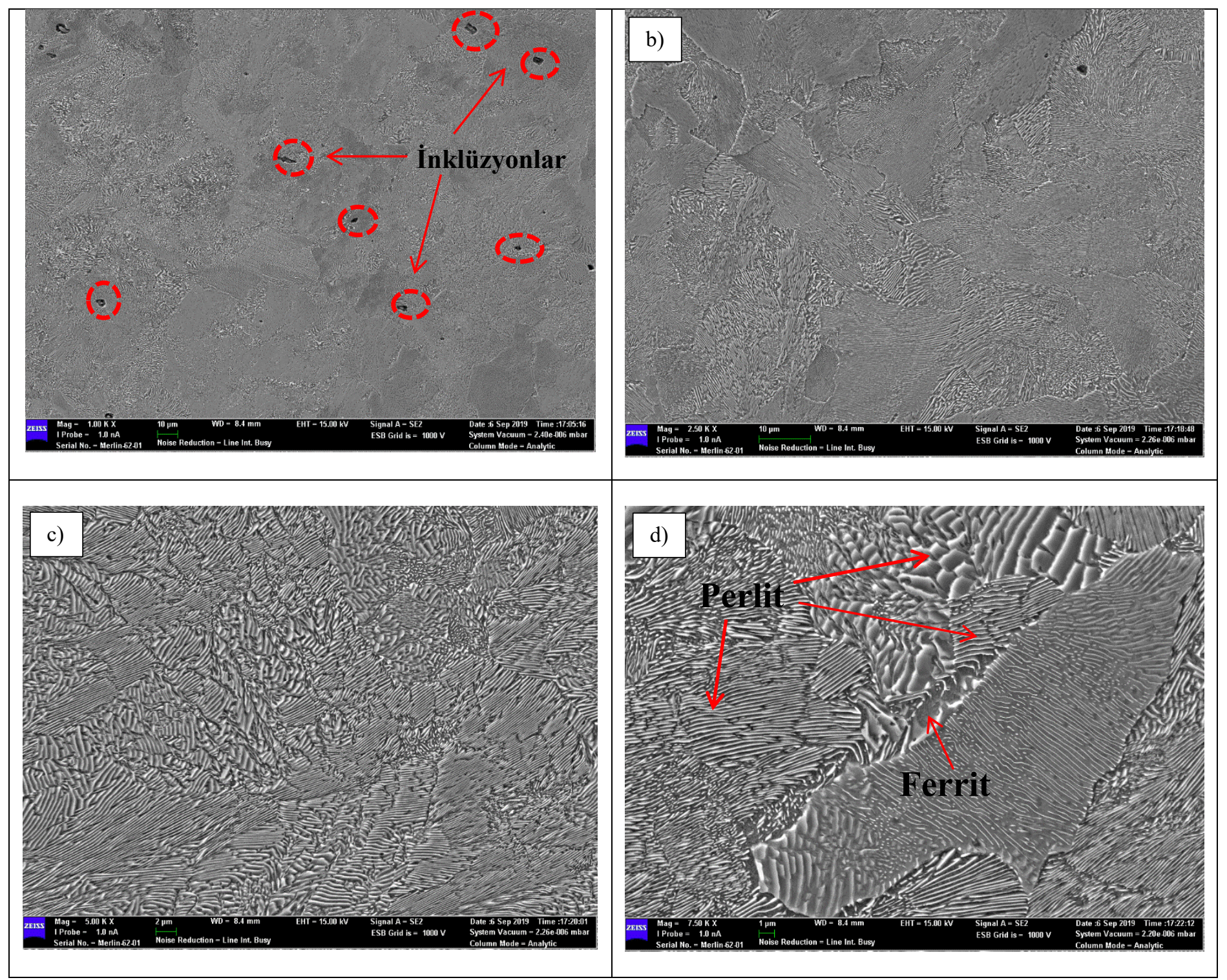

Şekil 12. Yanak (field corner) bölgesi SEM görüntüleri (ikincil elektron dedektörü) a) 250x büyütme b) 1500x büyütme, c) 2500x büyütme, d) $5000 x$ büyütme

\subsection{Ray Enine (Transverse) Kesitinde Makro İnceleme Sonuçları}

Teslim edilen ray parçalarının enine (transverse) kesitinde makro-dağlama yapılmış ve bu sonuçlara göre Şekil 13'de mantar ile gövde bölgeleri arası geçiş yerinde "merkez segregasyon" bölgesi gözlemlenmiştir [33].

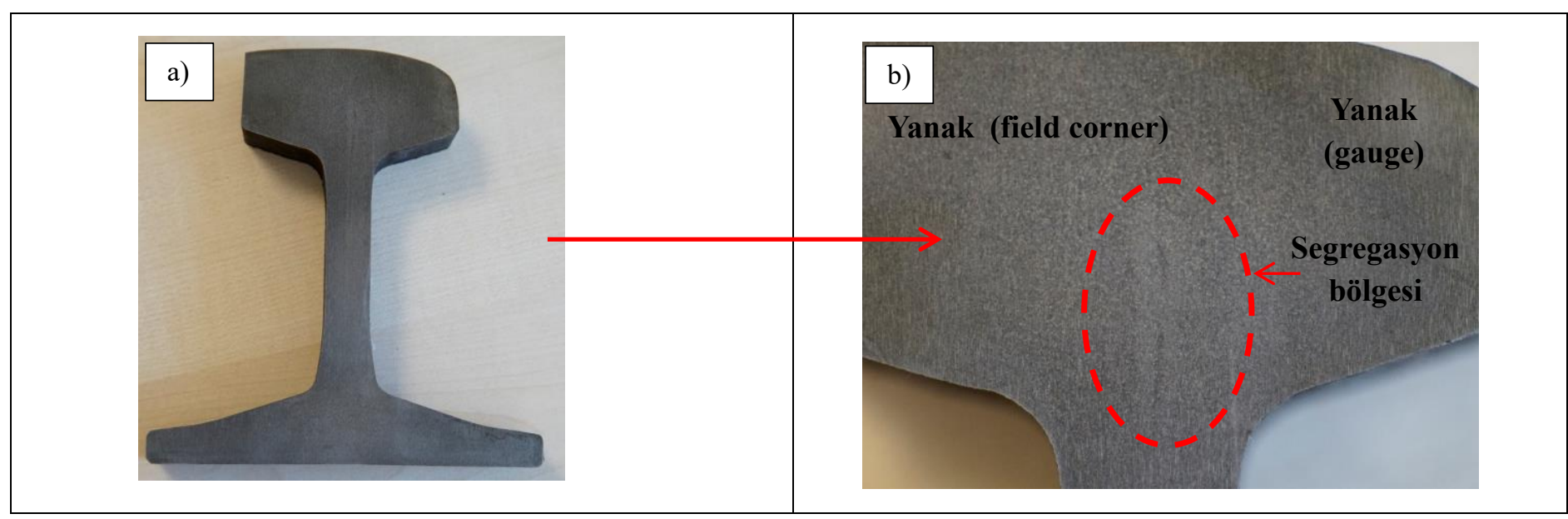

Şekil 13. Makro-inceleme yapılan enine (transverse) ray kesiti Mantar ile gövde bölgeleri arası geçiş yerinde gözlemlenen "merkez segregasyon" 


\subsection{SEM-EDS ile Mikro-Kimyasal Analiz Sonuçları}

SEM-EDS sistemiyle yapılan mikro-kimyasal analizler inklüzyonların ve oksit-sülfit (MnS) karışımı Şekil 14 veya sadece MnS (Sülfit) Şekil 15 ve 16 olduğunu göstermektedir. Nicel analiz sonuçlarına göre Şekil 15-16' da gözlemlenen inklüzyonların kimyasal orantılı (stokiyometrik) olarak MnS bileşiği olduğu ve bu inklüzyonların çelik yapımı sırasında oluşarak yapı içinde kaldığı belirlenmiştir. Alınan SEM görüntülerinde bu inklüzyonların yapı içindeki dağılımı homojen bir şekilde olduğu görülmüştür. İnklüzyonlar çelik yapımı sırasında (sıvı çelik içinde çeşitli tepkimeler sonucu ve katılaşma sırasında) veya sıvı çeliğin firın, pota ve döküm haznesi tuğlaları ile mekanik ya da kimyasal etkileşimi sonucu oluşabilirler. Mevcut çelikte oluşan inklüzyonlar "iç kökenli kalıntı” olarak adlandırılan birinci gruptaki kalıntılardır. İnklüzyonlar normal şartlarda içyapıda bulunması istenmez; ancak günümüz teknolojisinde bu kalıntılar sıfıra indirgenememektedir. İnklüzyonlar çeliklerin akma dayancı, kopma dayancı, süneklik, tokluk ve yorulma ömrü gibi mekaniksel özelliklerini olumsuz etkiler. Bu nedenle çelik yapısında mümkün olduğunca az sayıda, tüm yüzeye homojen ve eşit miktarda dağılmış olarak bulunmaları istenmektedir. Yanak-gauge bölgesinde çatlak altında da (Şekil 14) demir oksit partiküllerine rastlanmıştır. Bu durum çatlakların aniden değil, zaman içinde kullanıma ve atmosfer koşullarına bağlı olarak ilerlediğini ve çatlak ilerleyene kadar, çatlak yüzeylerinin oksitlendiğini göstermektedir.

Segregasyon MnS gibi bazı elementlerin katılaşma sırasında homojen dağılmaması sonucu oluşmaktadır. Bu heterojenlik malzeme özelliklerinde de değişimlere yol açmaktadır. Raylarda özellikle gövde kısmında belirgin bir segregasyon görülmemesi istenmektedir. Yapılacak inceleme ve kullanılan kabul kriterleri değişkenlik göstermekle birlikte, mevcut rayları durumu ise "sınırda" kabul edilebilir seviyededir [33].

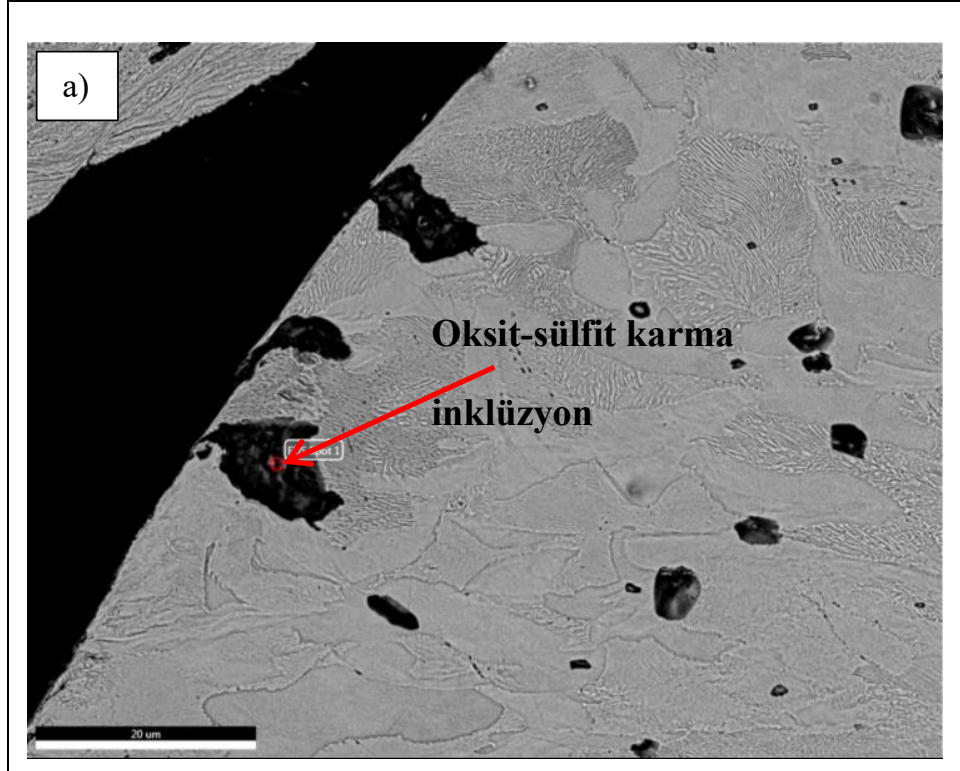

\begin{tabular}{cccc} 
b) & \multicolumn{3}{c}{ Nicel Analiz Sonuçlan } \\
Element & \% Ağırlık & \% Atom & Net Sinyal \\
C K & 11.68 & 28.48 & 624.16 \\
O K & 18.64 & 34.12 & 2906.38 \\
Si K & 0.68 & 0.7 & 190.79 \\
S K & 0.45 & 0.41 & 122.06 \\
Ca K & 1.64 & 1.2 & 289.78 \\
Mn K & 0.56 & 0.3 & 47.57 \\
Fe K & 66.35 & 34.79 & 4164.2 \\
\hline
\end{tabular}

c)

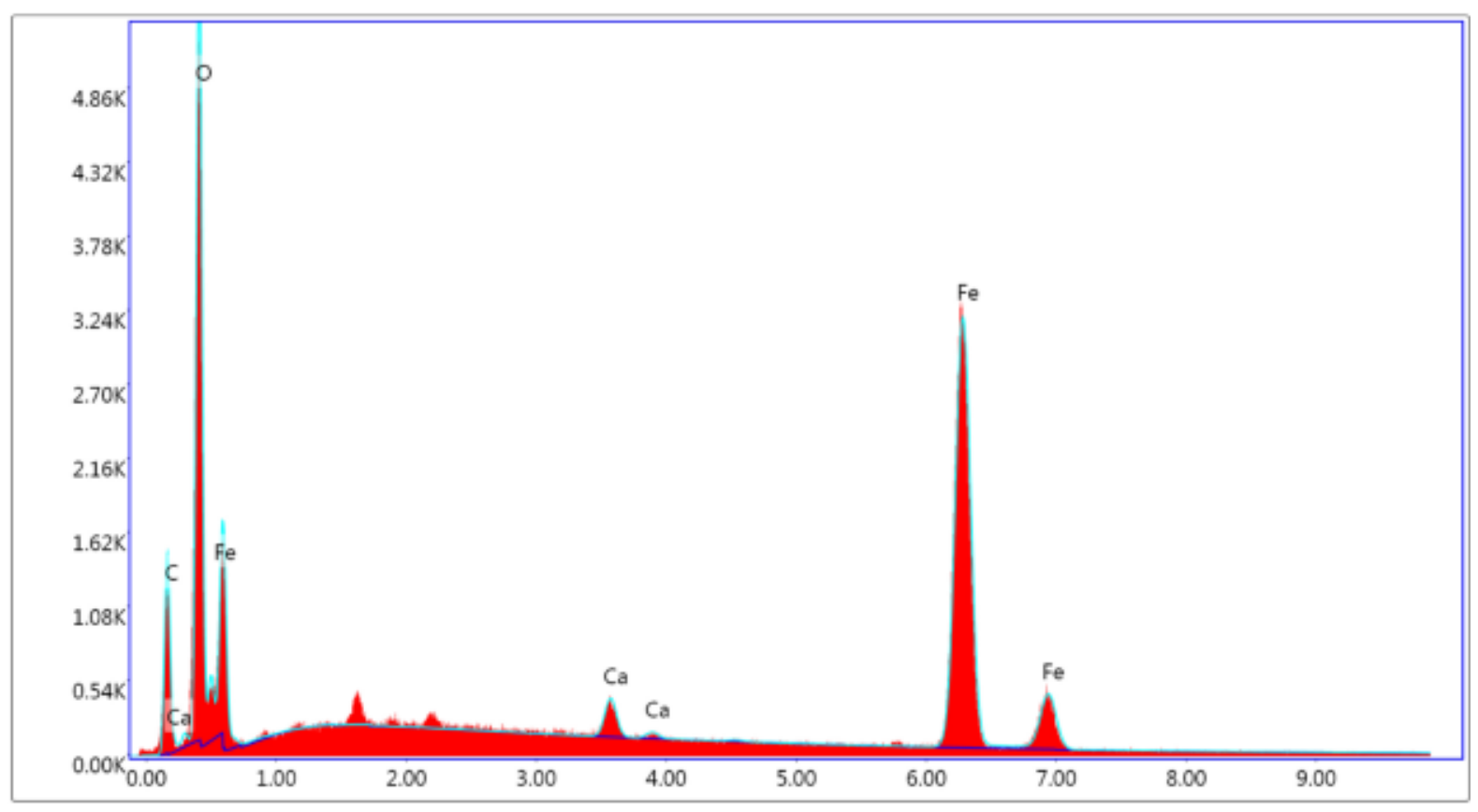

Şekil 14. SEM-EDS ile mikro-kimyasal analiz, Yanak-gauge bölgesi aşınma yüzeyi yakını oksit partikülü a) Geri saçılan elektron görüntüsü ve analiz alınan partikül, b) Nicel analiz sonuçları c) EDS spektrumu 


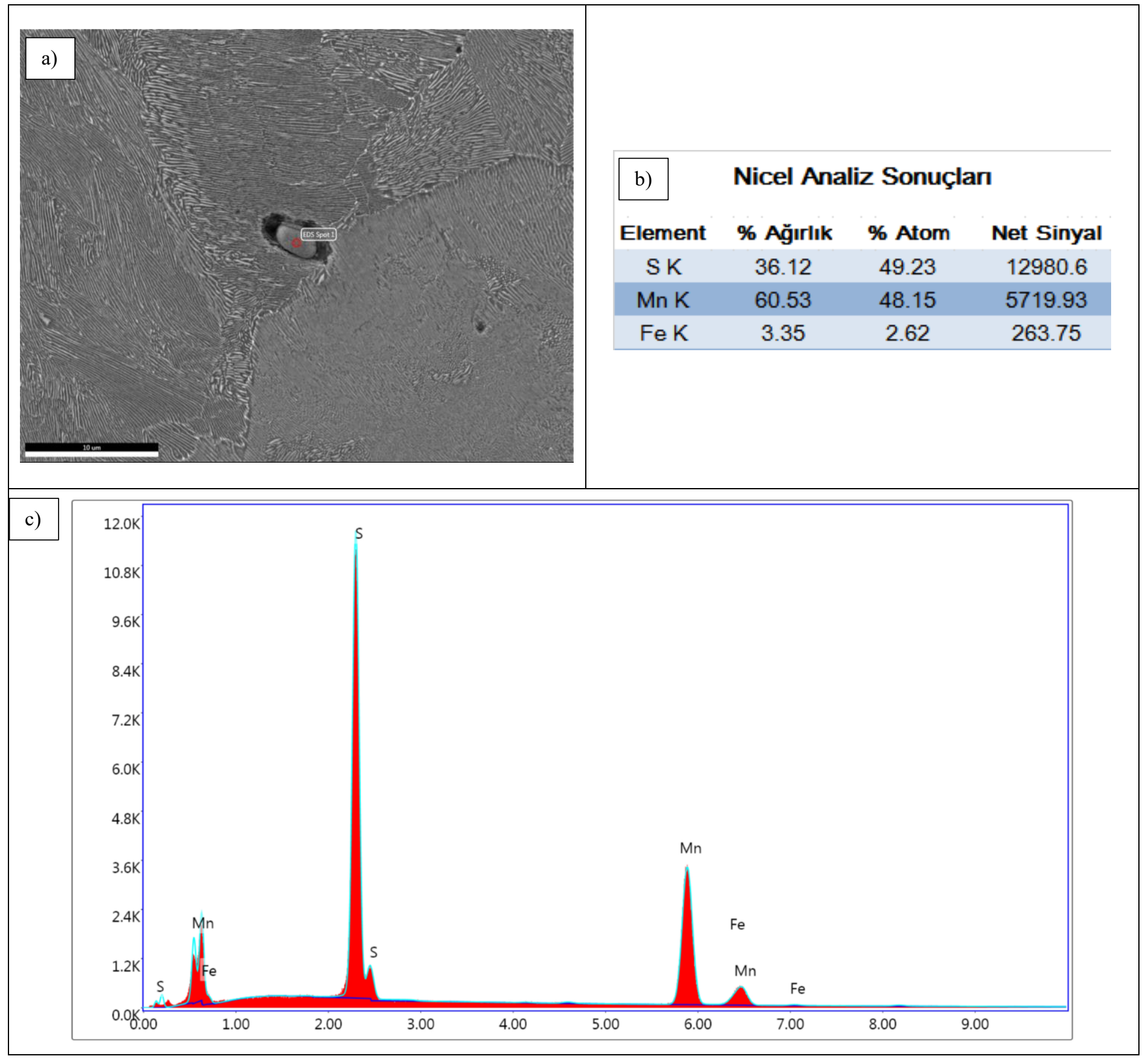

Şekil 15. SEM-EDS ile mikro-kimyasal analiz, Yanak (field corner) bölgesi aşınma yüzeyi yakını oksit partikülü, a) Geri saçılan elektron görüntüsü ve analiz alınan partikül, b) Nicel analiz sonuçlarl, c) EDS spektrumu 


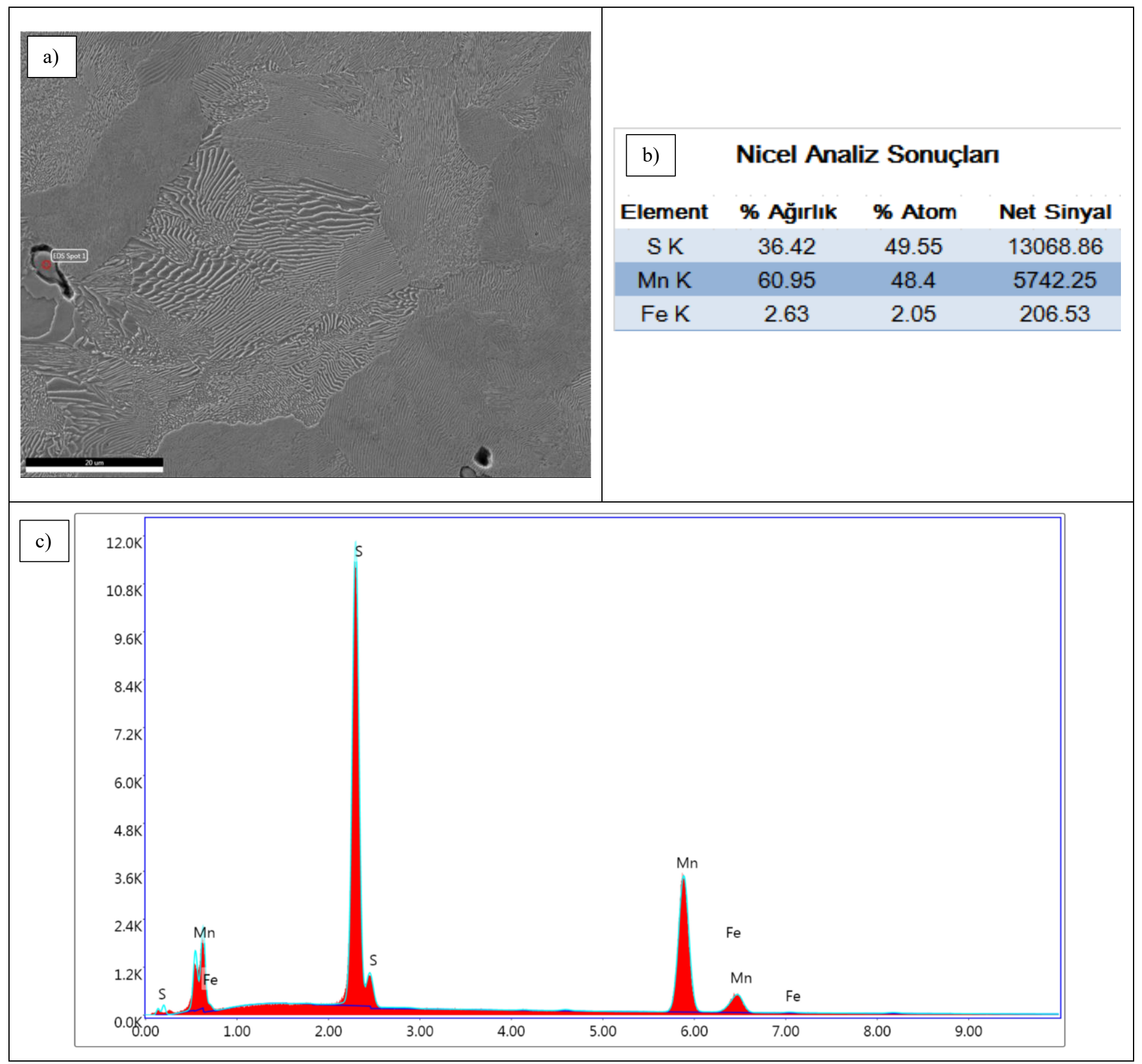

Şekil 16. SEM-EDS ile mikro-kimyasal analiz, Yanak-gauge bölgesi aşımma yüzeyi yakını oksit partikülü, a) Geri saçılan elektron görüntüsü ve analiz alınan partikül, b) Nicel analiz sonuçlarl, c) EDS spektrumu

\subsection{Makro-Kimyasal Analiz Sonuçları}

Ray parçalarının genel kimyasal kompozisyonları optik emisyon spektrometresi (OES) ile belirlenmiş ve Tablo 2'de verilmiştir. İlk etapta OES cihazının demir-çelik alaşımları için genel programı (Fe-Global) kullanılarak 5 yakımın ortalaması alınmıştır. Fe-global programı genel kompozisyonu belirlemek için uygun olsa da karbon, krom, fosfor ve kükürt gibi elementlerin belirlenmesinde hassasiyeti düşüktür. Sonrasında mevcut raylara da en uygun olan düşük alaşımlı çelik programı kullanılarak ikinci bir 5 yakımlık ölçüm gerçekleştirilmiştir. Ayrıca R260 kalite rayların standart kompozisyon aralığı da yine aynı tabloda belirtilmiş̧ir. Yüzde karbon $(\% \mathrm{C})$ değerleri alt sınıra yakın olmakla birlikte ölçüm sonuçları mevcut rayların R260 kalite için izin verilen kompozisyon aralığında olduğunu göstermektedir.

\subsection{Sertlik Ölçüm Sonuçları}

Metalografik inceleme için hazırlanan ray enine kesit plakaları üzerinde yapılan sertlik ölçüm sonuçları Tablo 3'de gösterilmiştir. Sertlik değerleri EN 13674-1 standardına göre B, F ve H bölgelerinden alınmıştır. Vickers mikro-sertlik ölçümleri (HV 0,2) ASTM E140 standardında verilen tablolar yardımıyla "Brinell (HBW) sertlik değerlerine çevrilmiştir (Tablo 4).

R260 kalite rayların kullanılmamış halde 260 - 300 HBW sertlik aralı̆̆ında olmaları beklenmektedir. Tüm bölgelerin sertlik değerleri eşik değer olan $260 \mathrm{HBW}$ 'nin üzerinde ölçülmüştür. Yuvarlanma yolu bölgesinin aşırı plastik deformasyona uğramayan 
yerlerinde ve teker temasının çok az olduğu yanak (field corner) bölgelerinde $268-284 \mathrm{HBW}$ arası sertlik değerleri bulunmuştur. Bu değerler R260'ın izin verilen sertlik aralığı içinde yer almaktadır. Öte yandan, yanak-gauge bölgesinde ise aşırı deformasyonun etkisiyle malzeme pekleşmeye uğramıştır. 341 HV (323 HBW) değeri ile B bölgesi (yanak-gauge) en sert bölgedir. Bu bölgede, kullanım öncesi gerek içyapı gerekse sertlik değerleri tahminen diğer yanak bölgesine benzerdi. Ancak kullanım sırasında aşırı deformasyon nedeniyle içyapıdaki değişiklikler malzemeyi pekleştirmiştir ve sertlikte artı̧̧a neden olmuştur [34].

Tablo 2. Kimyasal Kompozisyon -ölçüm değerleri ve R260 standart aralı̆̆l- \% ăğıllk cinsinden

\begin{tabular}{|c|c|c|c|c|c|c|}
\hline Kullanılan Metot & C & Si & Mn & $\mathbf{P}$ & S & Açıklama \\
\hline $\mathrm{Fe}-$ Global & 0,672 & 0,179 & 1,018 & $<0,005$ & $<0,150$ & $\begin{array}{l}\text { OES cihazının demir alaşımları için genel programıdır; } \\
\% \mathrm{P}, \% \mathrm{~S}, \% \mathrm{C} \text { değerlerini hassasiyeti düşüktür. }\end{array}$ \\
\hline Fe-LowAlloy & 0,683 & 0,683 & 0,236 & 1,027 & $<0,0005$ & $\begin{array}{l}\text { OES cihazının düşük alaşımlı çelikler için özel } \\
\text { programıdır, \%P, \%S, \%C ve alaşım elementlerini daha } \\
\text { hassas ve doğru olarak belirlenmesini sağlar. }\end{array}$ \\
\hline \multirow{2}{*}{$\begin{array}{l}\text { R260 Standart } \\
\text { Kompozisyonu }\end{array}$} & 0,620 & 0,150 & 0,700 & \multirow{2}{*}{$<0,025$} & \multirow{2}{*}{$<0,008$} & \multirow[t]{2}{*}[9,35]{ 'e göre standart kompozisyon aralığı } \\
\hline & 0,800 & 0,580 & 1,200 & & & \\
\hline
\end{tabular}

Tablo 3. Vickers sertlik testleri sonuçları (dh: Vickers izin yatay yönde uzunluğu, $d_{v}$ : Vickers izin dikey yönde uzunluğu, $d_{o r t}$ :Vickers izin yatay ve dikey yönlerde ölçülen uzunluklarının ortalaması

\begin{tabular}{|c|c|c|c|c|c|c|c|c|c|c|}
\hline Bölge & Test No & $\begin{array}{c}d_{h} \\
(\mu \mathrm{m})\end{array}$ & $\begin{array}{c}d_{v} \\
(\mu \mathrm{m})\end{array}$ & $\begin{array}{c}d_{\text {ort }} \\
(\mu \mathrm{m})\end{array}$ & $\begin{array}{c}\text { HV } \\
\mathbf{0 , 2}\end{array}$ & Ortalama & $\begin{array}{c}\text { Standart } \\
\text { Sapma }\end{array}$ & $\begin{array}{c}\% 95 \\
\text { Güven } \\
\text { Aralığı }\end{array}$ & $\begin{array}{c}\text { Bağıl } \\
\text { Doğruluk } \\
(\%) \\
\end{array}$ & $\begin{array}{c}\text { Sertlik } \\
\text { Değeri (HV } \\
0,2) \\
\end{array}$ \\
\hline \multirow{5}{*}{ Yanak-gauge } & 1 & 34,3 & 32,97 & 33,6 & 328 & \multirow{5}{*}{341,4} & \multirow{5}{*}{11,13} & \multirow{5}{*}{13,81} & \multirow{5}{*}{4,05} & \multirow{5}{*}{$\begin{array}{c}341,4+- \\
13,81\end{array}$} \\
\hline & 2 & 32,54 & 32,97 & 32,8 & 346 & & & & & \\
\hline & 3 & 31,66 & 32,97 & 32,3 & 355 & & & & & \\
\hline & 4 & 32,98 & 33,85 & 33,4 & 332 & & & & & \\
\hline & 5 & 33,42 & 32,09 & 32,8 & 346 & & & & & \\
\hline \multirow{5}{*}{ Yuvarlanma Yolu } & 1 & 37,82 & 36,92 & 37,4 & 266 & \multirow{5}{*}{283,4} & \multirow{5}{*}{10,67} & \multirow{5}{*}{13,24} & \multirow{5}{*}{4,67} & \multirow{5}{*}{$\begin{array}{c}283,4+- \\
13,24\end{array}$} \\
\hline & 2 & 34,74 & 36,49 & 35,6 & 292 & & & & & \\
\hline & 3 & 35,62 & 36,92 & 36,3 & 282 & & & & & \\
\hline & 4 & 36,06 & 35,17 & 35,6 & 292 & & & & & \\
\hline & 5 & 36,94 & 35,17 & 36,1 & 285 & & & & & \\
\hline \multirow{5}{*}{$\begin{array}{c}\text { Yanak (field } \\
\text { corner) }\end{array}$} & 1 & 36,94 & 35,17 & 36,1 & 285 & \multirow{5}{*}{299,2} & \multirow{5}{*}{8,47} & \multirow{5}{*}{10,51} & \multirow{5}{*}{3,51} & \multirow{5}{*}{$\begin{array}{c}299,2+- \\
10,51\end{array}$} \\
\hline & 2 & 34,3 & 35,61 & 35 & 304 & & & & & \\
\hline & 3 & 34,74 & 34,73 & 34,7 & 307 & & & & & \\
\hline & 4 & 35,62 & 34,73 & 35,2 & 300 & & & & & \\
\hline & 5 & 35,62 & 34,73 & 35,2 & 300 & & & & & \\
\hline
\end{tabular}

Tablo 4. Vickers sertliklerin (HV 0,2) ASTM E140 standardına göre Brinell Sertlik Değeri $(H B W)$ denkleri

\begin{tabular}{|c|c|}
\hline Vickers (HV 0.2) & Brinell (HBW) \\
\hline 341 & 323 \\
\hline 299 & 284 \\
\hline 283 & 268 \\
\hline
\end{tabular}

\section{Tartışma ve Sonuçlar}

$\mathrm{Bu}$ çalışmada Bursa ilinde kullanılan R260 kalite ray çeliklerinde meydana gelen soyulma ve kopmaların kök nedenini tespit etmek üzere numuneler üzerinden metalografik inceleme, kimyasal analiz ve sertlik testleri yapılmıştır.

Yapıdaki inklüzyonların varlığı ve dağıılımı parlatılmış numunelerin optik mikroskop altında, çelik ana yapısını oluşturan faz ve faz karışımları ise dağlanmış numunelerin optik mikroskop ve SEM altında incelenmesi ile belirlenmiştir. SEM-EDS analizleri ile yapıda gözlemlenen inklüzyon partiküllerinin kimyasal kompozisyonları belirlenmiştir.

Bu incelemeler sonucunda yapıda 10 mikron ve altı boyutlarda çok sayıda metal dışı kalıntılar (inklüzyon) gri ve siyah noktalar şeklinde tespit edilmiştir. Bu inklüzyonlar aşırı deformasyon nedeniyle oluşan çatlakların ray kesiti içine ilerlemesini kolaylaştırmaktadırlar. 
Özellikle kurplarda teker temasının arttığı, yanak-gauge bölgesinde ise aşınma olan yerlerde aşırı deforme olmuş, lamel yapının bozularak mikron-altı büyüklükte ferrit ve sementit dönüştügü gözlemlenmiştir. Așırı deforme olan yapıda çatlaklar oluşmuş ve daha az deforme olan bölgeyle aşırı deforme olan bölge arasında malzeme içlerine doğru ilerlemiştir. Çatlak ilerledikten sonra malzeme yüzeyinden parça kopmalarına da neden olmuştur. Bu noktada tekerle ray kesiti teması neticesinde yanak-gauge bölgesinde oluşan kesme tipi gerilimler de parça kopmalarını kolaylaştırmıştır.

Yapılan SEM inceleme sonucunda ray parçaların ana-yapısının neredeyse \%100 perlit olduğu gözlemlenmiştir. Rayların mantar bölgesi üzerinde yer alan yuvarlanma yolu bölgesinde de yanak-gauge bölgesine benzer şekilde aşırı deforme olarak bozulmaya başlamış perlitik yapı gözlemlenmiştir. Bu bölgede de çatlaklar oluşup iç kısımlara doğru ilerlemiştir. Öte yandan yanak-gauge bölgesinden farklı olarak temel yüklerin basma tipi olması ve çatlakların malzeme içine doğru ilerliyor olması yanak yüzeyindeki kadar kritik aşınmaları ve parça kopmalarını ciddi oranda azaltımıştır.

Ray Enine (Transverse) Kesitinde Makro İnceleme Sonuçları raylarda segregasyon olduğunu göstermekle birlikte mevcut rayları durumu uluslararası standartlara göre "sınırda" kabul edilebilir olduğu değerlendirilmiştir.

SEM-EDS ile Mikro-Kimyasal Analiz Sonuçlarına göre; çatlak etrafında ve Yuvarlanma yolu bölgesinde demir oksit partiküllerine rastlanmıştır. Bu durum çatlakların aniden değil, zaman içinde kullanıma ve atmosfer koşullarına bağlı olarak ilerlediğini ve çatlak ilerleyene kadar, çatlağın yüzeylerinin oksitlendiğini göstermektedir.

Makro-Kimyasal Analiz Sonuçları mevcut rayların R260 kalite için izin verilen kompozisyon aralığında olduğunu göstermektedir.

Tüm bölgelerin sertlik değerleri eşik değer olan 260 HBW'nin üzerinde ölçülmüsşür. Ray teker teması olan bölgelerde sertliğin daha yüksek olduğu gözlemlenmiştir. Aşırı plastik deformasyon etkisi ile pekleşme nedeniyle malzeme sertliği artmıştır.

Özetle mevcut rayların matris fazları, makro kimyasal kompozisyon ve sertlik değerleri açısından izin verilen aralıkta olduğu sonucuna varılmıştır. Öte yandan yapıda gözlemlenen çok sayıda inklüzyonun çatlak ilerlemesini kolaylaştırdığı ve kopmaları hızlandırdığı sonucuna varılmıştır.

Ray teker arası temas bölgelerindeki gerilmeler açısından mevcut raylarda gözlemlenen kusur, hataları oluşturması en muhtemel gerilme tipi ray üzerinde seyir halinde olan HRS seti yüklü araç ağırlığının neden olduğu düşey ve kesme gerilmeler olduğu düşünülmektedir. Dingil yüklerinin artması ile temas yüzeyinde oluşan kesme tipi gerilimin şiddeti artmaktadır. Çekiş katsayısı (traction coefficient, ratio of tangential to normal forces) $\mathrm{T} / \mathrm{N}$ değerine bağlı olarak soyulmaların yüzeyde mi yüzey altından mı başlayacağını belirlenebilmektedir. Genel olarak 0,2 'ye kadar olan $\mathrm{T} / \mathrm{N}$ değerleri en yüksek kesme gerilmelerinin ray-teker temas yüzeyinin biraz altında oluşmasına, yani soyulmaları başlatacak çatlakların yüzey yerine yüzey altından başlamasına sebep olmaktadır. Dingil yüklerinin artması normal yükleri artırarak $\mathrm{T} / \mathrm{N}$ oranının düşmesine ve soyulma başlangıcını oluşturacak yüzey-altı çatlak başlangıçlarına neden olmaktadir.

UIC 712 R'de ray kusurları/hataları görüldüğü ray sonunda (1), ray sonu harici diğer bölgeler (2), rayın hasar görmesinden kaynaklanan arızalar (3), kaynak ve yüzey yenileme kusurları (4), ana başlıklarına göre, örnek olarak ray mantarında oluşan yatay çatlaklar 112, 212, yuvarlanma yüzeyinin kabuklanması 2221, ray mantarında oluşan kılcal çatlak 2223, ray mantarında oluşan düşey aşınmalar 2204, alüminotermit kaynak kesitinde oluşan yatay çatlak 422 şeklinde UIC kodları ile sınıflandırılmaktadır.

Yapılan incelemeler sonucunda incelenen rayların yanak-gauge ve yuvarlanma yolu bölgelerinde yuvarlanma değme yorulması (RCF - Rolling contact fatigue) kaynaklı aşınma ve parça kopmaları oluştuğu sonucuna varılmışırı. Bu yorulma tip ray üzerinde birden farklı tipte hata oluşturabilmektedir. Temel olarak ray-teker ara yüzünde aşırı miktarda kesme tipi gerilimlerin (shear stress) varlığı bu RCF tipi yorulmaya neden olmaktadır. Mevcut numunelerde RCF'nin bir alt-grubu olan "kabuk soyma" (shelling) gözlemlenmiştir (Şekil 2,3) Bu soyulmalar genellikle yanak-gauge köşe bölgesinin 2 ile $8 \mathrm{~mm}$ altında başlar ve çoğunlukla kurblarda üstte kalan raylarda gözlemlenir. Kabuk soyma ray-hattı boyunca düzenli olarak gözlemlenmez ve başlangıçlarında yanak-gauge bölgesinde siyah noktalar şeklinde kendini gösterir. Ray yüzeyine 10 ile 30 derece açı yaparak iç bölgelere doğru büyürler. Çatlakların büyümesi raylardan kabuk soyma şeklinde parça kopmasına veya rayın enine kesiti boyunca çatlak ilerlemesine ve fark edilemezse rayın kopmasına neden olabilir. Çeliğin yapısındaki metal dışı kalıntılar vb. süreksizlikler de çatlak başlangıcına neden olabilir; mevcut çatlağın ilerlemesini hızlandirabilir.

Yuvarlanma değme yorulması nedeniyle oluşmaya başlatan kabuk soyma hataları ray-teker ara yüzünde mevcut ray malzemesinin limitlerinin üzerinde kesme gerilimleri oluşması nedeniyle başlar. Kesme tipi gerilimleri etkileyen faktörler teker çapları (küçük tekerler daha yüksek gerilimlere neden olur), teker-ray ara yüzündeki temas bölgesinin yarıçapı [36], nominal, dinamik ve darbe tipi teker yükleri, hat geometrisi, araç (vagon takımı) karakteristikleri ve çekiş gücü olarak sıralanabilir [37, 38].

$\mathrm{Bu}$ sonuçlar ve değerlendirme neticesinde, çatlamayı önleyici faaliyetler kapsamında aşağıdaki maddeler önerilmektedir.

Kurp gibi kritik bölgelerde daha yüksek dayanımlı (350 HT) rayların kullanılması; bu sayede izin verilen kesme tipi gerilim limitlerinin artırılması ve benzer şekilde mantarı sertleştirilmiş rayların kullanımı raylarda aşınmayı ve plastik deformasyonu azaltacaktır [39-42].

Kullanılan ray çeliklerin inklüzyon miktarı ve büyüklüğü açısından temiz olması, mevcut çeliğe göre daha temiz çeliklerin kullanılması önerilmektedir. Çeliklerde inklüzyon miktarı kontrolü ASTM E45, DIN 50602 veya EN10247 gibi standartlara göre gerçekleştirilmeli ve alım şartnamesinde belirtilmelidir [43, 44].

Teker ve/veya rayların yağlanma (lubrication) prosedürleri iyileştirilebilir. Bu iyileştirmeler aynı zamanda ray tekerlek kırılma ve aşınmalarının önlenmesini ve yakıt tasarrufu sağlamaktadır [40]. 
RCF tipi hataların ilerlemesini kontrol edebilmek adına işletmenin belirlediği Tablo 5'de belirtilen taşlama bakım periyodlarında yapılan ray bakım işlemleri uygulanmaktadır. Tablodaki değerler her işletmenin kendi hatlarının taşıdığı yıllık trafik miktarına ve kurbun çapına göre değişkenlik göstermektedir. Ray malzemesi harcanmasına neden olan taşlama işlemlerinin genel paso alma yerine $(0,05$ $0,1 \mathrm{~mm}$ ) RCF-tipi aşınmayla başlayan ve kenarların soyulmasına neden olan çatlakların ilerleme hızını azaltmak adına özellikle kritik lokasyonlardaki çatlak kontrollerinin daha sık yapılarak taşlama işleminin yapılması, raya gelen yüklerle çatlağın derine ilerlemesini azaltacaktır. RCF tipi kusurların görülen bölgelerde girdap akımları (eddy-current) yöntemi ile ölçüm yapan cihaz ile çatlak boyutlarının tespit edilerek ölçülen çatlak derinliğinden $+0,1 \mathrm{~mm}$ güven payı da üzerine konularak kılcal çatlak (head check) taşlaması yapılmalıdır. $\mathrm{Bu}$ önleyici taşlama işlemiyle yüzeyden genellikle $0,2-0,5 \mathrm{~mm}$ aralığında malzeme kaldırılması tavsiye edilmektedir. Taşlama sonrasında yanak (gague) bölgesinde çıplak gözle görünür çatlak kalmamış olması önemlidir. Bu sayede çatlakların malzeme içine ilerleyerek parça kopmalarının önüne geçilebilmektedir $[9,45]$.

Rayın yüzeyinde bulunan çatlaklıkların, girdap akımları yöntemi ile ölçüm yapan cihazlar ile ölçüm yapılarak çatlak derinliğinin 0,3 mm'yi geçtiği bölgelerde frezeleme (milling) aracı ile ray yüzeyinden sorunlu malzemenin kaldırılması işlemi taşlama işlemine göre daha etkili olmaktadır. Tek seferde alınan paso frezelemede (en düşük 0,25-0,3 mm) taşlamaya (en düşük $0,01 \mathrm{~mm}$ ) göre daha fazladır. Taşlama makinası ile artan talaş kaldırma miktarı (taşlamanın son aşaması da dahil), ray malzemesinin yapısal değişikliğinin bir işareti olan bir renk şeridi oluşturur. Ray mantarının yapısı artan sıcaklık nedeniyle değişir ve mevcut korumasını kaldırır. Mevcut kılcal çatlaklar daha hızlı büyümeye devam edebilir. Bu yüzden çatlak ölçüm sonuçlarından hareket edilerek bu bölgelerde frezeleme yapılması tavsiye edilmektedir.

Tablo 5. İşletmenin belirlediği kurp yarıçapına göre koruyucu bakım taşlama periyodları

\begin{tabular}{|c|c|}
\hline R: Kurp yarıçapı (m) & Koruyucu bakım taşlama periyodu (ay) \\
\hline $\mathrm{R}<150$ & 2 \\
\hline $150<\mathrm{R}<300$ & 4,5 \\
\hline $300<\mathrm{R}<500$ & 8 \\
\hline
\end{tabular}

Teker-ray temas karakteristiklerinin iyileştirilmesi yapılabilir. Bu iyileştirilmeler teker-ray temas gerilimlerini ve yanaklardaki kesme tipi gerilimleri azaltmayı hedeflemelidir. Kurpların dönüş açısı, dış-tarafın yüksekliği, teker geometrisi ve ölçüsel toleranslar gözden geçirilmelidir [10,46]. Bu iyileştirmeler aynı zamanda işletmenin özellikle $\mathrm{R}<400$ kurplarında iç rayda oluşan ondülasyon probleminin de önüne geçecektir. İşletmede ondülasyon ölçümü (dalga boyları ve derinlikleri) kontrolleri yapılarak derinlik $0,2 \mathrm{~mm}$ üstüne çıkılmadan taşlama işlemi yapılmaktadır.

Özellikle son önerilen maddenin gerçekleştirilebilmesi için R125 - dever 100, R150 - 150 dever kurp bölgelerinde belirlenen sabit araç hızlarında $(35,40,50 \mathrm{~km} / \mathrm{s})$ farklı araç setlerinin raya binen yüklerin dağılımının hesaplanması, dinamik davranış ölçümlerinin yapılması gerekmektedir. Ayrıca; tüm sistem elemanlarının modelinin çıkartılarak simülasyon programında eşik değerlerin tanımlanması ve olası trafik ve sefer yüklerinin artması ile gelecek yatrımların planlanması ve hat güzergahlarının ve seyir ile ilgili teknik sınırların hat ve araç özelliklerine bağlı çıkartılması sürdürülebilir bir model geliştirilmesi planlanmalıdır.

\section{Kaynakça}

[1] A. Uğur, "Demiryolu Sektöründe Dünya Gelişme Beklentileri ve Türkiye'nin Durumunun Araştırılması", Alphanumeric Journal, vol. 7 (2), 369-398, 2019.

[2] J. Xu, L. J. Butler, \& M. Z. Elshafie, "Experimental and numerical investigation of the performance of self-sensing concrete sleepers", Structural Health Monitoring, vol. 19, no. 1, 66-85, 2020.

[3] J. Jiang, Z. Chen, W. Zhai, T. Zhang, \& Y. Li, "Vibration characteristics of railway locomotive induced by gear tooth root crack fault under transient conditions", Engineering Failure Analysis, vol. 108, 104285, 2020.

[4] L. Ferreira, \& M. H. Murray, "Modelling rail track deterioration and maintenance: current practices and future needs", Transport Reviews, vol. 17, no. 3, 207-221, 1997.

[5] J.-A. Zakeri, M. Fathali, \& N. B. R, "Effects of Rail Cant on Wheel-Rail Contact Forces in Slab Tracks", International Journal of Mechanics and Applications, vol. 1(1), 12-21, 2011.

[6] H. Jiang, \& L. Gao, "Optimizing the Rail Profile for High-Speed Railways Based on Artificial Neural Network and Genetic Algorithm Coupled Method", Sustainability, vol. 12, no. 2, 658, 2020.

[7] C. He, J. Liu, W. Wang, \& Q. Liu, "The Tribo-Fatigue Damage Transition and Mapping for Wheel Material under Rolling-Sliding Contact Condition", Materials, vol. 12, no. 24, 4138, 2019.

[8] R. Chen, C. Hu, J. Xu, P. Wang, J. Chen, \& Y. Gao, "An Innovative and Efficient Method for Reverse Design of Wheel-Rail Profiles", Applied Sciences, vol. 8, no. 2, 239, 2018.

[9] R. Lewis, \& U. Olofsson, "Wheel-rail interface handbook", India, USA: Woodhead Publishing Limited and CRC Press LLC, 2009.

[10]D. F. Cannon, K. O. Edel, S. L. Grassie, \& K. Sawley, "Rail defects: an overview", Fatigue \& Fracture of Engineering Materials \& Structures, vol. 26, no. 10, 865-886, 2003.

[11]U. Zerbst, R. Lundén, K. O. Edel, \& R. A. Smith, "Introduction to the damage tolerance behaviour of railway rails - a review", Engineering Fracture Mechanics, vol. 76, no. 17, 2563-2601, 2009.

[12]R. Masoudi Nejad, K. Farhangdoost, \& M. Shariati, "Microstructural analysis and fatigue fracture behavior of rail steel", Mechanics of Advanced Materials and Structures, vol. 27, no. 2, 152-164, 2020. 
[13]D. Mansouri, P. Sendur, \& G. G. Yapici, "Fatigue characteristics of continuous welded rails and the effect of residual stress on fatigue-ratchetting interaction", Mechanics of Advanced Materials and Structures, 1-8, 2018.

[14]P. Gurubaran, M. Afendi, M. A. Nur Fareisha, M. S. Abdul Majid, I. Haftirman, \& M. T. A. Rahman, "Fatigue life investigation of UIC 54 rail profile for high speed rail”, Journal of Physics: Conference Series, vol. 908, 012026, 2017.

[15]V. Arli, Demiryolu Mühendisliği, İstanbul: Marmara Kırtasiye ve Yayıncılık, 2015.

[16]M. Jimenez-Martinez, "Manufacturing effects on fatigue strength", Engineering Failure Analysis, vol. 108, $104339,2020$.

[17]J. Sadeghi, \& H. Askarinejad, "Influences of Track Structure, Geometry and Traffic Parameters on Railway Deterioration", International Journal of Engineering, vol. 20, no. 3, 292-300, 2007.

[18]A. K. Wilson, M., TMS 226 RailCorp Engineering Manual - Track Rail Defects Handbook, RailCorp Network, 1-83, 2012.

[19]Z. Li, D. Yi, C. Tan, \& B. Wang, "Investigation of the stress corrosion cracking behavior in annealed 5083 aluminum alloy sheets with different texture types", Journal of Alloys and Compounds, vol. 817, 152690, 2020.

[20]F. Wu, Q. Li, S. Li, \& T. Wu, “Train rail defect classification detection and its parameters learning method", Measurement, vol. 151, 107246, 2020.

[21]C. Taştimur, Karaköse. M, \& Akın, E, “A comparison study of rail fault detection methods in the literature”, in International Conference on Advances and Innovations in Engineering, 987-992, 2017.

[22]A. D. Sara.Teidj, Abdellatif. Khamlichi, "Detection of Damage in Rail Head by using Safe Method", Transactions on Machine Learning and Artificial Intelligence, vol. 5, no. 4, 2017.

[23]A. R. Khan, Y. Shengfu, \& H. Wang, "Influence of Heat Input and Preheating on Microstructure and Mechanical Properties of Coarse Grain Heat-Affected Zone of Metal Arc Gas-Welded Pearlitic Rail Steel”, Journal of Materials Engineering and Performance, vol. 28, no. 12, 7676-7686, 2019.

[24]S. Khoddam, A. H. Shamdani, P. Mutton, R. Ravitharan, J. H. Beynon, \& A. Kapoor, "A new test to study the cyclic hardening behaviour of a range of high strength rail materials", Wear, vol. 313, no. 1, 43-52, 2014.

[25]C. Jessop, J. Ahlström, C. Persson, \& Y. Zhang, "Damage evolution around white etching layer during uniaxial loading", Fatigue \& Fracture of Engineering Materials \& Structures, vol. 43, no. 1, 201-208, 2020.

[26]M. Aquib Anis, J. P. Srivastava, N. R. Duhan, \& P. K. Sarkar, "Rolling contact fatigue and wear in rail steels: An overview", IOP Conference Series: Materials Science and Engineering, vol. 377, 012098, 2018.

[27]M. Hiensch, \& M. Steenbergen, "Rolling Contact Fatigue on premium rail grades: Damage function development from field data", Wear, vol. 394-395, 187-194, 2018.

[28]S. R. Lewis, S. Fretwell-Smith, P. S. Goodwin, L. Smith, R. Lewis, M. Aslam, D. I. Fletcher, K. Murray, \& R. Lambert, “Improving rail wear and RCF performance using laser cladding", Wear, vol. 366-367, 268-278, 2016.

[29]UIC-712 R, "Rail defects”, International Union of Railways (UIC), UIC, Paris, Fransa, 2002.

[30]Australian Rail Track Corporation Ltd., "Manual for non-destructive testing of rail”, ARTC, Avustralya, 2009.

[31]Australian Rail Track Corporation Ltd., "Some Rail Defects, their Characteristics, Causes and Control”, Rail Defects Handbook, RC 2400, ARTC, Avustralya, 2006.

[32]T. Kato, H. Kato, \& T. Makino, "Effect of elevated temperature on shelling property of railway wheel steel”, Wear, vol. 366-367, 359-367, 2016.

[33]UIC-860 R, “Technical specification for the supply rail”, International Union of Railways (UIC), UIC, Paris, Fransa, 2008.

[34]D. Benoit, B. Salima, and R. Marion, "Multiscale characterization of head check initiation on rails under rolling contact fatigue: Mechanical and microstructure analysis", Wear, vol. 366-367, 383-391, 2016.

[35]A. E. L. P. R. S. Sections, “Grooved Rails for Tramways Technical Manual”, ArcelorMittal Commercial RPS, Lüksemburg, 2018.

[36]J. Xu, P. Wang, L. Wang, \& R. Chen, "Effects of profile wear on wheel-rail contact conditions and dynamic interaction of vehicle and turnout", Advances in mechanical Engineering, 8(1), 1-14, 2016.

[37]J. Ahlstrom, B. Karlsson, "Microstructural evaluation and interpretation of the mechanically and thermally affected zone under railway wheel flats", Wear, vol. 232, 1-14, 1999.

[38]G. G. Knupp, W. H. Chidley, J. L. Giove, H. H. Martman, G. F. Morris, C. W. Taylor, "A Review of the Manufacture, Processing, and Use of Rail Steels in North America", A Report of AISI Technical Subcommittee on Rails and Accessories In Rail Steels, Developments, Processing, and Use. ASTM International, 1978.

[39]R. K. Steele, "Rail: Its behaviour and Relationship to Total System” Wear, 2nd Heavy Haul Railways Conf. Proc. Colorado, 115$165,1982$.

[40]H. Muster, H. Schmedders, K. Wick, \& H. Pradier, "Rail rolling contact fatigue. The performance of naturally hard and headhardened rails in track", Wear, vol. 191, 54-64, 1996.

[41]M. Tomičić-Torlaković, "Guidelines for the rail grade selection”, Metalurgija, 53(4), 717-720, 2014.

[42]P. J. Bolton, P. Clayton, I. J. McEwen, "Wear of Rail and Tyre Steels under Rolling/Sliding Conditions", ASLE Transactions, Vol. 25, No. 1, 17-24, 1982.

[43]A. Melander, "A finite element study of short cracks with different inclusion types under rolling contact fatigue load", International Journal of Fatigue, 19(1), 13-24, 1997.

[44]Y. Neishi, T. Makino, N. Matsui, H. Matsumoto, M., Higashida \& H. Ambai, "Influence of the inclusion shape on the rolling contact fatigue life of carburized steels", Metallurgical and Materials Transactions A, 44(5), 2131-2140, 2013.

[45]P.A. Cuervo, J. F. Santa, A. Toro. "Correlations between wear mechanisms and rail grinding operations in a commercial railroad", Tribology International, 82, 265-273, 2015.

[46]D. F., Cannon, H. Pradier, "Rail rolling contact fatigue", Research by the European Rail Research Institute, International Journal of Fatigue, 10(19), 722, 1997. 